\title{
Dynamics of phytoplankton communities in eutrophying tropical shrimp ponds affected by vibriosis
}

\author{
Lemonnier Hugues ${ }^{1,{ }^{*}}$, Lantoine François ${ }^{2}$, Courties Claude ${ }^{2}$, Guillebault Delphine ${ }^{2,3}$, \\ Nézan Elisabeth ${ }^{4}$, Chomérat Nicolas ${ }^{4}$, Escoubeyrou Karine ${ }^{5}$, Galinié Christian ${ }^{6}$, Blockmans Bernard ${ }^{6}$, \\ Laugier Thierry ${ }^{1}$
}

1 IFREMER LEAD, BP 2059, 98846 Nouméa cedex, New Caledonia, France

${ }^{2}$ Sorbonne Universités, UPMC Univ Paris 06, UMR 8222, LECOB, Observatoire Océanologique, F66650 Banyuls/mer, France

${ }^{3}$ Microbia Environnement, Observatoire Océanologique de Banyuls, 66650 Banyuls-sur mer, France

${ }^{4}$ IFREMER, LER BO, Station de Biologie Marine, Place de la Croix, BP 40537, 29185 Concarneau Cedex, France

${ }^{5}$ Sorbonne Universités, UPMC Univ Paris 06, CNRS, Plate-forme Bio2Mar, Observatoire Océanologique, F-66650 Banyuls/Mer, France

${ }^{6}$ GFA, Groupement des Fermes Aquacoles, ORPHELINAT, 1 rue Dame Lechanteur, 98800 Nouméa cedex, New Caledonia, France

* Corresponding author : Hugues Lemonnier, email address : hugues.lemonnier@ifremer.fr

\begin{abstract}
:
Tropical shrimp aquaculture systems in New Caledonia regularly face major crises resulting from outbreaks of Vibrio infections. Ponds are highly dynamic and challenging environments and display a wide range of trophic conditions. In farms affected by vibriosis, phytoplankton biomass and composition are highly variable. These conditions may promote the development of harmful algae increasing shrimp susceptibility to bacterial infections. Phytoplankton compartment before and during mortality outbreaks was monitored at a shrimp farm that has been regularly and highly impacted by these diseases. Combining information from flow cytometry, microscopy, pigment and phylogenetic analysis, the presence of Picocyanobacteria, Prasinophyceae and Diatomophyceae were detected as dominant phytoplankton groups and Cryptophyceae, Prymnesiophyceae and Dinophyceae as minor components. At the onset of the first shrimp mortalities, Bacillariophyceae increased while Cyanobacteria, Prymnesiophyceae and Dinophyceae decreased in the water column, followed by proliferation of Prasinophyceae. Several taxa were identified as potential harmful algae (Cyanobacteria, dinoflagellates and Phaeocystis).
\end{abstract}




\section{Highlights}

- Phytoplankton dynamic was investigated in shrimp ponds before and during vibriosis. Picocyanobacteria, Prasinophyceae and Diatomophyceae were found as dominant. Environmental conditions were characterized by strong phytoplankton oscillations. Several taxa were identified as potential harmful algae.

Keywords: Tropical aquaculture pond, Litopenaeus stylirostris, Vibriosis, Eutrophication, Phytoplankton, Harmful algae 


\section{Introduction}

The world shrimp industry regularly faces major crises due to outbreaks of serious bacterial or viral infections (Flegel, 2012; Tran et al., 2013). In the literature, it is increasingly agreed that diseases will be the limiting factor for future food supply from the crustacean aquaculture sector (Stentiford et al., 2012). As observed in various shrimp species and locations elsewhere in the world, shrimp aquaculture in New Caledonia (Litopenaeus stylirostris) is affected by epizooties. During the warm and cold seasons, two types of vibriosis induce shrimp mortalities in growing ponds, threatening the economic viability of the industry. Epidemiological studies have revealed that the first type of vibriosis results from the highly pathogenic (HP) Vibrio nigripulchritudo ( $\mathrm{Vn}$ ) strain and that the colonization of the shrimp pond ecosystem by this particular pathogenic cluster occurs at the onset of the disease outbreak (Goarant et al., 2006ab; Reynaud et al., 2008; Le Roux et al., 2010; Goudenège et al., 2013). Known as "Summer Syndrome", this disease is currently restricted to one particular area of New Caledonia (St Vincent Bay). Regarding this epizooty, three risk factors were identified for shrimp mortality occurrence and strength: fast shrimp growth, early eutrophication of the pond ecosystem, and the presence of the HP Vn strain (Lemonnier et al., 2006). The second type of vibriosis is related to Vibrio penaeicida (Vp) and is known as “Syndrome 93" (Costa et al., 1998; Goarant et al., 1999; Saulnier et al., 2000). This pathogen is frequently detected in waters pumped from the lagoon, which are suspected to be the main source of pond bacterial contamination (Goarant et al., 1999; Goarant and Merien, 2006). Syndrome 93 disease is observed in all shrimp ponds of New Caledonia when temperature suddenly drops (Mermoud et al., 1998). High shrimp density at the onset of the disease is the main risk factor of this vibriosis (Lemonnier, 2007). Whatever the disease, mortality appears in specific environmental conditions characterized by strong phytoplankton and bacterioplankton oscillations and abiotic parameters ( $\mathrm{pH}$, ammonia, etc.) close to stressful values (Lemonnier et al., 2006; 2010; Lucas et al., 2010). Such conditions, which may occur 
in combination with another unknown triggering factor, weaken the host physiological status, parameters, increasing shrimp susceptibility to bacterial infections (Mugnier et al., 2013). The sudden collapse of some phytoplankton populations suggested weak ecosystem stability and the loss of homeostatic mechanisms. This lack of stability may promote the development of toxic algal species increasing the risk of infection. The close relationship between the incidence of shrimp diseases and the surrounding microbial community has been well established by several authors (Kautsky et al., 2000; Zhang et al., 2014). However, our knowledge of phytoplankton community diversity and dynamics in ponds, particularly harmful algae, is still too fragmentary to fully understand the mechanisms triggering and/or promoting disease outbreaks (Casé et al., 2008).

With the help of a farmer, a study was conducted in industrial ponds to monitor phytoplankton composition and dynamics before and during mortality outbreaks. The farm concerned has been regularly and severely impacted by both types of vibriosis for several years. Flow cytometry (FCM) was used to describe the phytoplankton community changes, because this technique is one of the most efficient for monitoring rapid microbial population changes within the water column (Courties and Boeuf, 2004). The statistical reliability of abundance is better than microscopic cell counts as greater proportion of cells (thousands) can be analysed over shorter period (seconds) (Troussellier et al., 1993). Potentially toxic phytoplankton species were searched in all samples collected during mortality outbreaks, using optical microscopy. To describe more accurately and specifically the phytoplankton communities, complementary approaches were combined on several samples. Taxonomic groups of phytoplankton were identified by HPLC analysis according to their marker pigments. Various photopigments characterize specific phytoplankton taxonomic groups (chlorophytes, cryptophytes, cyanobacteria, diatoms and dinoflagellates) (Paerl et al., 2003; Jeffrey et al., 2011). This technique has also been shown to be useful for the detection of fragile flagellates, which are destroyed by procedures used for microscopic observations. This 
technique, known as chemotaxonomy, has been widely and successfully used in marine, estuarine and freshwater environments (Jeffrey et al., 1997; Descy et al., 2009), but has been applied less frequently to tropical aquaculture ponds (Burford, 1997; Gárate-Lizárraga et al., 2009). Metagenomic analysis of flow-sorted selected cells was conducted on one fresh sample to estimate the diversity of two dominant cytometric groups: picoeukaryotes, which are highly abundant, and an unknown prokaryotic group regularly observed in shrimp ponds in New Caledonia (Courties and Boeuf, 2004; Lucas et al., 2010). The combination of cell sorting by FCM with molecular tools allows the molecular taxonomic identification of specific planktonic cells (Guillebault et al., 2010).

\section{Material and methods}

\subsection{Field survey}

The field survey was conducted during the 2009 - 2010 austral summer, in two ponds, named $\mathrm{C}$ and D. These ponds have been regularly impacted by vibriosis for several years. The stocking date chosen for this field survey was particularly favourable to the occurrence of the diseases (Lemonnier et al., 2006). The ponds were managed by the farmer according to his usual techniques without advices from scientific team. The ponds (around 8 ha) were dried for more than one month before breeding shrimps and supplied with blue shrimp (L. stylirostris) post-larvae $(0.03 \mathrm{~g})$ at 22 individual. $\mathrm{m}^{-2}$ on the 19 October 2009 . Shrimps were fed on a daily basis with commercial food containing between 35 and $40 \%$ protein. Daily water renewal increased in pond D from 5 to $30 \%$ between the beginning and the end of the rearing. To test the effect of water exchange rates (WER) on disease outbreak, WER applied by the farmer were voluntary lower in pond $\mathrm{C}$ than in pond D. There was no mechanical aeration. During rearing, shrimp mortality was estimated by counting dead and moribund shrimp at the pond edges or on the filters located on the effluent gates. This estimation should be viewed in this study as a qualitative method. Isolation of the pathogen strains was conducted from 
hemocultures of 30 moribund shrimp. The different strains isolated were phylogenetically identified using molecular-based tools (Goarant et al., 2006b; 2007). The survival rate (\%) calculated by the farmer was estimated by the ratio of the number of harvesting shrimp at the end of the rearing to the number of stocking shrimp at the beginning of the rearing.

\subsection{Sampling and field data}

The sampling strategy was based on previous studies that showed a good mixing of the water column (Lemonnier et al., 2010). One sampling station was representative of the whole pond. Thus, water sampling was carried out early in the morning (between 6 am and 8 am, local time) by the farmer at a station located near the pond discharge-gate. Sampling was scheduled three times a week over a period ranging from the 30th rearing day (d30) to the end of the rearing (d180). Surface water samples were collected using a 2-L polyethylene bottle. Procedures used in this study to measure water physico-chemical parameters (salinity, temperature, dissolved oxygen (DO), Secchi) have already been fully described in Lemonnier et al. (2006).

\subsection{Laboratory analysis}

\subsubsection{Chlorophyll a}

Water samples (20 to $50 \mathrm{ml}$ ) were filtered through a Whatman GF/F filter then stored frozen at $-20^{\circ} \mathrm{C}$ prior to analysis. Total chlorophyll a (TChl $a$ ) and pheophytin were determined using a fluorimeter (Turner Desings TD700, Sunnyvale, CA, USA) in accordance with the method described by Holm-Hansen et al. (1965). To estimate the size fractioned chl $a$, a first subsample was filtered through $2 \mu \mathrm{m}$ Nucleopore to obtain biomass $>2 \mu \mathrm{m}$ (1). The size fractions $<20 \mu \mathrm{m}$ were obtained using $20 \mu \mathrm{m}$ nylon sieve pre-filtered sub-samples filtered onto Whatman GF/F filter (2). The size fractioned chl $a(<2 \mu \mathrm{m} ; 2$ to $20 \mu \mathrm{m}$; and $>20 \mu \mathrm{m})$ were calculated using data from (1), (2) and TChl $a$. Picoplankton is classified as having cell sizes smaller than $2 \mu \mathrm{m}$, nanoplankton as having cell sizes between 2 and $20 \mu \mathrm{m}$, and 
microplankton as having cell sizes greater than $20 \mu \mathrm{m}$.

\subsubsection{Optical microscope analysis}

This approach aimed to detect potential toxic phytoplankton species in the samples collected during mortality outbreaks. Preservation of $100 \mathrm{ml}$ of five samples was directly implemented on site with $1 \%$ Lugol's iodine solution (final concentration) stored in the dark. Microscopic screening was achieved at the Ifremer laboratory using a counting chamber and inverted microscope $(\mathrm{N}=5)$. Five other samples were collected at the same farm in 2010 and 2011 during mortality outbreaks to complete our sampling campaign and to identify more precisely certain taxa. After microscopic screening, cells were further identified using single cell PCR methodology (Auinger et al., 2008).

\subsubsection{Flow cytometry analysis (FCM)}

Freshwater $2 \mathrm{ml}$ subsamples were preserved with $1 \%$ glutaraldehyde (final concentration) stored in liquid nitrogen pending flow cytometric analysis (Vaulot et al., 1989). Quickly thawed at room temperature, samples were then analysed using a FACSCan flow cytometer (BD-Biosciences, San Jose, CA) equipped with an air-cooled argon laser (488 nm, $15 \mathrm{~mW}$ ). Phytoplankton cells were discriminated and enumerated on the basis of their right-angle light scattering properties (SSC, roughly related to cell size), and orange $(560-620 \mathrm{~nm})$ and red (> $670 \mathrm{~nm}$ ) fluorescence due to phycoerythrin and chlorophyll pigments, respectively. Data acquisition was performed using CellQuest software (BD-Biosciences). Fluorescent $1.002 \mu \mathrm{m}$ beads (Polysciences Inc., Europe) used as an internal standard were systematically added to each analysed sample. Mean cell fluorescence and light scatter were standardized by dividing them by the homologue signals of beads, thus making results comparable. Accurate analysed volumes - varying between 225 and $400 \mu \mathrm{l}$ - and subsequent estimations of cell concentrations were calculated by measuring the remaining volume and subtracting it from 
the initial subsample volume $(1 \mathrm{ml})$. Accuracy and precision of the procedure were described by Trousselier et al (1993) and more recently by Bouvier et al. (2001).

\subsubsection{HPLC pigments analysis}

Water samples (150 to $250 \mathrm{ml}$ ) were filtered through Whatman filters $(\mathrm{GF} / \mathrm{F}, 47 \mathrm{~mm}$ diameter) immediately frozen. The size fractions of 2-20 $\mu \mathrm{m}$ were obtained using $20 \mu \mathrm{m}$ nylon sieves pre-filtered sub-samples filtered onto $2 \mu \mathrm{m}$ Nucleopore membranes. Pigments were extracted from both sets of filters at $4^{\circ} \mathrm{C}$ using $3.4 \mathrm{ml}(\mathrm{GF} / \mathrm{F})$ and $1.8 \mathrm{ml}$ (Nucleopore) of $100 \%$ acetone. Extracts were centrifuged four hours later at $2900 \mathrm{rpm}$ and filtered through a $0.2 \mu \mathrm{m}$ PTFE filter. HPLC analyses were performed on an Ultimate 3000 Dionex system equipped with a diode array detector following a protocol adapted from Zapata et al. (2000). The separation was done with a Phenomenex Luna C8 column (150 x 4.6mm, $3 \mu \mathrm{m})$. Most pigments were detected at $440 \mathrm{~nm}$, while chlorophyll-a and its derivatives were detected at $667 \mathrm{~nm}$ and phaeopigments at $410 \mathrm{~nm}$. Pigment concentrations were calculated from the peak areas with an internal standard correction (Vitamin E acetate, Sigma) and external calibration standards (DHI Water and Environment, Denmark). Accuracy and precision of the calibration were $0.6 \%$ and $0.2 \%$ respectively.

Phytoplankton composition was determined from pigment analysis using CHEMTAX version 1.95 software, program developed by Mackey et al. (1996) to calculate the contribution from different phytoplankton groups to chl $a$, based on ratios between accessory pigments and chl $a$. The phytoplankton taxa selected to be included in this program were determined on the basis of previous reports on the equatorial Pacific (Mackey et al., 1996; Higgins and Mackey, 2000; DiTullio et al., 2003, Higgins et al., 2006) and tropical Indian ocean (Schlüter et al., 2011) and all the information obtained via flow cytometric counting, microscopic observation, molecular analysis and previous studies on the same environment (Lucas et al., 2010). Photoacclimation processes were taken account on the basis of pigment ratios published by 
Laviale and Neveux (2011). The following nine algal pigment taxa were selected: chlorophytes, prasinophytes 3 (prasinoxanthin containing prasinophytes) (Higgins et al., 2011) and prasinophyte 1-2 (without prasinoxanthin), pelagophytes (Andersen et al., 1993), cryptophytes, diatoms, haptophytes Type 6, (Zapata et al., 2004), dinoflagellates (with peridin), cyanobacteria represented by Synechococcus (type 2 cyanobacteria) (Jeffrey and Wright, 1997). The pigments used for fitting the algal class abundances were: chlorophyll $c 1$ (chl c1), c2 (chl c2), c3 (chl c3), peridin (PERI), 19'-butanoyloxyfucoxanthin (BUT), fucoxanthin (FUCO), 19'-hexanoyloxyfucoxanthin (HEX), neoxanthin (NEO), prasinoxanthin (PRAS), violaxanthin (VIOLA), alloxanthin (ALLO), lutein (LUT), zeaxanthin (ZEA), TChl $b$, TChl $a$. The pigment ratio matrix is presented in Table 1 .

\subsubsection{Metagenomic analysis}

Two populations regularly observed at high abundances in shrimp ponds (UNK and PEUK) were collected in pond C in December 2010 and one hundred thousand cells of each population were immediately sorted using a FACSAria flow cytometer (BD Biosciences) and processed according to Guillebault et al. (2010). The $16 \mathrm{~S}$ and $18 \mathrm{~S}$ rRNA genes were sequenced using next generation sequencing (Research and Testing Laboratory, Texas, USA). Sequences were trimmed and quality-checked then clustered in phylogenetic groups or Operational Taxonomic Units (OTU) using the Clusterer software using the UPGMA settings at a similarity threshold of 98\% (Stackebrandt and Ebers 2006; Klepac-Ceraj et al., 2006). The closest relatives were searched in the SILVA 100 ARB databases, RDP taxonomic classifier (bootstrap value $\geq 80 \%$ ) and GenBank databases (Pruesse et al.,2007; Cole et al., 2009).

\section{Results}

\section{Zootechnical results and mortality in ponds}

After 249 and 209 days of rearing, final shrimp survivals and yields were $42 \%$ and $2.6 \mathrm{tha}^{-1}$ 
and $23 \%$ and $1.3 \mathrm{t} \mathrm{ha}^{-1}$ in ponds $\mathrm{C}$ and $\mathrm{D}$, respectively. Feed conversion ratio (FCR) commonly expressed as the ratio of feed mass input to body mass output were 2.5 in ponds $\mathrm{C}$ and 3.4 in pond D. First mortalities were observed in both ponds between d63 and d69 when average individual shrimp weight was about $5 \mathrm{~g}$. These mortalities were linked to $V p$ presence. Two main chronicle mortality periods were observed thereafter: the first in pond C occurred between d105 and d165 and the second in pond D between d133 and d154. In pond D, $V n$ and $V p$ were identified at $\mathrm{d} 141$ in $86 \%$ and $14 \%$ of the moribund shrimp, respectively. Due to a low number of moribund shrimp, pathogen identification was not possible in pond C.

\section{Environmental factors}

This survey started at the beginning of the hot season (October) and ended at the beginning of the cold season (May). Temperature showed the same seasonal pattern in both ponds with an irregular increase from the beginning until the middle of the surveys followed by a decrease at the end (Fig. 1). During the first part of the survey, the temperature suddenly dropped from $28.3^{\circ} \mathrm{C}$ at $\mathrm{d} 45$ to $24.0^{\circ} \mathrm{C}$ at $\mathrm{d} 60$, followed by the first mortality event in both ponds. A second temperature drop was observed after d136 (from $28.6^{\circ} \mathrm{C}$ to $22.4^{\circ} \mathrm{C}$ ). Daily minimal recorded temperature averaged $24.9 \pm 1.7^{\circ} \mathrm{C}(\mathrm{N}=168)$. The minimal value observed at the beginning of the rearing was $20.5^{\circ} \mathrm{C}$. Between $\mathrm{d} 0$ and $\mathrm{d} 135$, minimum dissolved oxygen (DO) in pond $\mathrm{C}$ decreased from 6 to $2 \mathrm{mg} \mathrm{l}^{-1}$. Thereafter, DO increased until the end of the rearing. Pond D showed minimal values ranging from 4 to $8 \mathrm{mg}^{-1}$ throughout the rearing. The daily minimum mean values $(\mathrm{N}=165)$ were $5.0 \pm 1.2 \mathrm{mg} \mathrm{l}^{-1}$ in pond $\mathrm{C}$ and $5.7 \pm 0.9 \mathrm{mg} \mathrm{l}^{-1}$ in pond $\mathrm{D}$. Maximal values recorded in the afternoon ranged from 5 to $14 \mathrm{mg}^{-1}$ in both ponds.

\section{Total chlorophyll a}

Chlorophyll $a$ concentration showed a complex pattern with a succession of increasing and decreasing phases (Fig. 2). At the beginning of the survey after one month of increasing 
biomass of phytoplankton, a decrease coinciding with decreasing temperature and the first mortality events was observed. After a new increase of chlorophyll biomass, a further decrease was observed after d130 coinciding again with the second mortality event in pond D. The concentrations were in general higher in pond $\mathrm{C}$ than in pond $\mathrm{D}$, displaying mean concentrations of $29.0 \pm 12.1 \mu \mathrm{g} \mathrm{l}^{-1}(\mathrm{~N}=44)$ and $18.4 \pm 9.3 \mu \mathrm{g} \mathrm{l}^{-1}(\mathrm{~N}=44)$, respectively.

\section{Cytometric diversity}

For both ponds, cell types were categorized in seven main cytometric groups. Cells were identified as: SYN for Synechococcus sp., UNK for unknown cells, PEUK for picoeukaryotes, NAN1, NAN2 and NAN3 for nanophytoplankton (type 1, 2 and 3) and CRY for cryptophytes. UNK, SYN and PEU signatures belong to picoplankton size class, with a size below 2 $\mu \mathrm{m}$, while the others were considered as nanoplanktonic cells. NAN1, NAN2 and NAN3 signatures corresponded to different nanoplanktonic populations showing an increasing relationship between their normalized SSC and FLR properties, which could be attributed to their cell size and chlorophyll content. On the basis of the results found using the metagenomic approach (see below), UNK was considered to be Cyanobacteria.

\section{Prokaryotic algae abundance}

As observed for Tchl $a$, prokaryotic algae abundance showed a complex pattern with succession of increasing and decreasing phases. One month after the beginning of the survey, a decrease of cell abundances coinciding with the first mortality events was observed. After a new increase of abundance, a further decrease was observed around d100 coinciding, once again, with the beginning of the chronicle mortality period observed in pond C. For the two procaryotic picoplankton cell types, UNK and SYN, very high peaks were found before d60 and around $\mathrm{d} 85$ in both ponds. At these times, abundances were exceptionally high, with total 


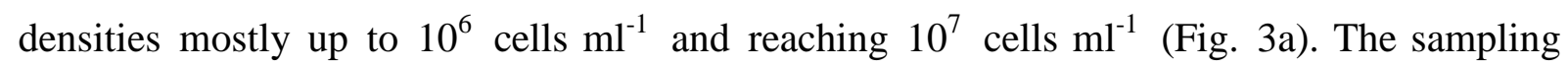
conducted after d120 showed lower cell densities, below $4 \times 10^{6}$ cells $\mathrm{ml}^{-1}$ until the last sampling day.

\section{PEUK populations}

In pond $\mathrm{C}$, the highest PEUK abundances $\left(<0.2 \times 10^{6} \mathrm{ml}^{-1}\right)$ were found during the first sampling period, i.e. between d30 and d100 (Fig. 3b). In pond D, the pattern was similar during the first part of the survey. A high peak was observed from d120 to d150, reaching a maximum of $0.92 \times 10^{6}$ cells $\mathrm{ml}^{-1}$ and followed by an abundance decrease.

\section{Nanoplankton populations}

On the basis of SSC/1 $\mu \mathrm{m}$, the nanophytoplankton type 1 (N1) signature represents the smaller nanoplankton discriminated by FCM. For both ponds, N1 abundances were lower than $20 \mathrm{x}$ $10^{3}$ cells $\mathrm{ml}^{-1}$ (Fig. 3c). These abundances were generally lower in pond D (mean \pm S.D.: 5.7 $\pm 4.2 \times 10^{3}$ cells $\mathrm{ml}^{-1} ; \mathrm{N}=33$ ) than in pond $\mathrm{C}\left(\right.$ mean: $7.6 \pm 6.8 \times 10^{3}$ cells $\left.\mathrm{ml}^{-1} ; \mathrm{N}=32\right)$. The nanophytoplankton type $2(\mathrm{~N} 2)$ abundance was low in pond C, generally less than $3 \times 10^{3}$ cells $\mathrm{ml}^{-1}$ (Fig. 3d). A bloom was observed after d161 at the end of the sampling period. At this time, cell abundance reached a maximum of $29.4 \times 10^{3}$ cells $\mathrm{ml}^{-1}$. In contrast, pond D was characterized by one peak close to $12 \times 10^{3}$ cells $\mathrm{ml}^{-1}$ at its maximum on $\mathrm{d} 60$, while cell concentration was usually below $2 \times 10^{3}$ cells $\mathrm{ml}^{-1}$ during the sampling period. As in pond $\mathrm{C}$, a bloom was observed at $\mathrm{d} 161$.

Nanoplanktonic type 3 (N3) sporadic blooms were detected during the second part of the sampling and were at their maximum on d133 and d149 with abundances reaching $3.9 \times 10^{3}$ cells $\mathrm{ml}^{-1}$ (Fig. 3e). The cryptophytes showed strong growth that occurred at days $37-63$ in pond $\mathrm{C}$ and reached more than $257 \times 10^{3}$ cells $\mathrm{ml}^{-1}$ at $\mathrm{d} 58$ when prokaryotic picoplankton 
concentrations were highest (Fig. 3f). A sporadic peak was also observed at d147 $\left(189 \times 10^{3}\right.$ cells $\mathrm{ml}^{-1}$ ). For ponds $\mathrm{D}$, cryptophytes were regularly represented at cell concentrations below $25 \times 10^{3}$ cells $\mathrm{ml}^{-1}$.

\section{Microscopic analysis during mortality outbreaks}

During mortality outbreaks, three nanoplanktonic diatoms, Chaetoceros minimus, Thalassiosira sp. $\left(15 \times 10^{3}\right.$ cells $\left.\mathrm{ml}^{-1}\right)$, and Cyclotella sp. $\left(14 \times 10^{3}\right.$ cells $\left.\mathrm{ml}^{-1}\right)$, and one cyanobacteria Anabaenopsis sp. $\left(23 \times 10^{3}\right.$ cells $\left.\mathrm{ml}^{-1}\right)$ were observed as major taxa. The dinoflagellate Prorocentrum rhathymum was found at low abundance. Karenia mikimotoi, Karlodinium veneficum, two species of the family Pfiesteriaceae, Luciella masanensis and Stoeckeria sp., Heterocapsa pygmaea $(<20 \mu \mathrm{m})$, Protoperidinium cf. bipes, and three unknown nanoplanktonic dinoflagellates belonging to the order Peridiniales were also identified in the samples.

Size-fractionated Chl a biomass before, at the beginning of and after mortality outbreaks Figure 4 shows the results for the size-fractionated TChl $a$ of 10 water samples. Picophytoplankton dominated the phytoplankton biomass, particularly at the beginning of the survey. Picophytoplankton and nanophytoplanton represented an average value of $63 \pm 12 \%$ $(39-77 \%)$ and $26 \pm 9 \%(8-18 \%)$ of the total biomass, respectively. One important observation is the absence of microphytoplankton at $\mathrm{d} 37$ and $\mathrm{d} 43$. The microphytoplanktonic biomass reached around $50 \%$ of the total phytoplanktonic biomass at $\mathrm{d} 63$ in pond $\mathrm{D}$. These results show an increase of the microphytoplankton proportion just before the first mortality event (d63).

Pigment diversity before, at the beginning of and after the mortality outbreaks CHEMTAX calculations showed three dominant groups (biomass) present throughout the 
survey for the two ponds: cyanobacteria, prasinophytes 1-2, and diatoms. All other taxa were only minor groups with maximum abundance of $3 \%$ for dinophytes, cryptophytes and chlorophytes in few situations (Fig. 5). Pelagophythes, haptophytes and prasinophytes 3 were only sporadically present. The two ponds showed the same general trend with decreasing proportion of cyanobacteria from $70 \%$ to $31 \%$ in pond $\mathrm{C}$ and 60 to $19 \%$ in pond $\mathrm{D}$, while relative biomass of prasinophytes $1-2$ increased from $24 \%$ to $41 \%$ in pond $\mathrm{C}$ and from $10 \%$ to $48 \%$ in pond D. For diatoms, while pond C showed a general increase of diatoms proportion from $3 \%$ to $25 \%$, it was not so clear for pond D.

A major difference between the two ponds' temporal variability appeared at d63. Pond D showed a strong decrease of cyanobacteria in favour of diatoms (57\%), prasinophytes 1-2 (36\%) and some cryptophytes (3\%), while pond C produced the same order of abundance for cyanobacteria (37\%), diatoms (32\%) and prasinophytes $3(28 \%)$, with $2 \%$ of dinoflagellates instead of cryptophytes. Note that this major difference between the two ponds coincided with the first mortality period.

Within the $2-20 \mu \mathrm{m}$ size fraction (Fig. 6), there was also a difference between the two ponds at days $\mathrm{d} 37$ and $\mathrm{d} 43$, when diatoms were clearly dominant in pond $\mathrm{D}(74 \%)$ and diatom, cyanobacteria and prasinophytes 1-2 were combined in pond C. At d49, relative biomasses of the three major taxa were similar in the two ponds. Abundance of dinophytes (3\%) was low at $\mathrm{d} 43$ for pond $\mathrm{C}$ and at $\mathrm{d} 49$ for pond $\mathrm{D}$.

\section{Phylogenetic analyses of the UNK and picoeukaryotes populations}

Abundances of the UNK and PEUK populations were determined by FCM in the initial sample and were estimated at around $4.35 \times 10^{6}$ cells $\mathrm{ml}^{-1}$ and $2.37 \times 10^{6}$ cells $\mathrm{ml}^{-1}$, respectively. Tables 2 and 3 show the results of the phylogenetic analysis of the $16 \mathrm{~S}$ and $18 \mathrm{~S}$ ribosomal RNA gene sequences conducted for these two populations sorted by cell-sorting FCM. 
The PEUK group was largely represented by eukaryotic cells and mainly affiliated to the Plantae kingdom, whereas the UNK fraction was largely composed of prokaryotic sequences. The PEUK fraction was characterized by two main phyla: Chlorophyta and Bacillariophyta. Fifteen percent of the Chlorophyta phylum sequences were classified down to the Mamiellales order without genus affiliation, even though $80 \%$ of the sequences were similar to the genus Mamiella (Prasinophyceae). The Bacillariophyta phylum was highly dominant and included Chaetocerotales (2212 sequences), Cymatosirales (1795 sequences), Fragilariacales (90 sequences) and Achnanthales (18 sequences). The most represented species were Chaetoceros calcitrans and Arcocellulus mammifer, with $45.4 \%$ and $38.8 \%$ of the sequences respectively, whereas other species were present in low proportions, i.e. Arcocellulus polymorphus $(0.5 \%)$, an unknown species of Arcocellulus (1.8\%) and Minutocellus polymorphus (0.5\%).

The UNK group revealed few sequences among the eukaryotic domain with its main representative among the Cymatosirales order. This group was mainly prokaryotic and was represented by the Proteobacteria, Cyanobacteria and Bacteroidetes phyla in high proportions, $59 \%, 32 \%$ and $7 \%$ respectively. Within the Cyanobacteria phylum, $30 \%$ of the sequences were affiliated to Synechococcus and $34 \%$ to the bacteria Candidatus pelagibacter.

\section{Discussion}

Phytoplankton biomasses reported in this study were within the range of values generally found in semi-intensive or intensive ponds containing Penaeus monodon (Burford, 1997; Yusoff et al., 2002), Litopenaeus vannamei (Gárate- Lizárraga et al., 2009) or L. stylirostris (Lemonnier et al., 2006; 2010; Lucas et al., 2010; Thomas et al., 2010). The HPLC results confirm our previous FCM observations showing that picoplanktonic Cyanobacteria numerically dominate the picoplankton community. In New Caledonian coastal waters, Synechococcus numerically dominates in the bays (Jacquet et al., 2006; Thomas et al., 2010). These populations are regularly introduced into ponds $\left(\sim 100 \times 10^{3}\right.$ cells $\left.\mathrm{ml}^{-1}\right)$ during daily 
water renewal. Their small size minimizes their sinking velocity but also gives them a high area-to-volume ratio, thereby optimizing light utilization and nutrient absorption efficiencies in nutrient-depleted environments as generally is observed during the first phase of the shrimp rearing (Lemonnier et al., 2010). The turbidity increase resulting from bioturbation by shrimp and the eutrophication of the ecosystem due to food input by farmers are possible factors accounting for the decrease of picocyanobacteria abundance over rearing time (Gin et al., 2003). The dominance of these autotrophic prokaryotes has already been well established in tropical shrimp ponds in New Caledonia at the beginning of rearing. Abundances measured at this farm (up to $16 \times 10^{6}$ cells $\mathrm{ml}^{-1}$ ) were high compared to values previously reported $(<7 \mathrm{x}$ $10^{6}$ cells $\mathrm{ml}^{-1}$ ) in other farm ponds impacted but not systematically as observed here by vibriosis (Lemonnier et al., 2010; Lucas et al., 2010). Using Chemtax, chl $a$-containing cyanobacteria in this study ranged from $2 \%(\mathrm{~d} 63$, pond $\mathrm{D})$ to $70 \%(\mathrm{~d} 37$, pond $\mathrm{C})$ of the total chl $a$ biomass. Thus, this group could, during certain periods, be the major contributor to biomass and primary productivity of the water column in these eutrophic ecosystems. As also observed in previous studies conducted in New Caledonia (Lemonnier et al., 2010; Lucas et al., 2010), the fall in picocyanobacteria abundances coincided with the beginning of shrimp mortality events. The potential harmful effect of picocyanobacteria on shrimp has never been reported but several assays have indicated that some Synechococcus marine strains contain toxic compounds for marine invertebrates (Martins et al., 2007; Frazão et al., 2010). This finding emphasizes the need to increase our knowledge about Picocyanobacteria diversity and potential toxicity, especially during the senescence period, in order to assess their impact on shrimp health. FCM data showed that the red fluorescence can be used to discriminate two cyanobacterial populations (SYN and UNK). Courties et al. (2005) distinguished three different picocyanobacteria ribotypes through the $16 \mathrm{~S}$ ribosomal genes sequencing of DNA extracted from $3 \mu \mathrm{m}$ filtered water of a New Caledonian shrimp pond. Further work should be carried out in order to improve the assessment of the different picocyanobacteria group 
contributions to the total biomass and thus understand the ecological importance of these populations in the shrimp pond ecosystem.

In the present study, pigment analysis suggested that the biomass attributed to nano- and micro-phytoplanktonic cyanobacteria (blue-green algae) was weak comparatively to biomass attributed to picocyanobacteria. Blue-green algae are generally considered undesirable in aquaculture ponds, as they have a low nutritional potential, are an ineffective oxygenator and may produce odorous and toxic metabolites. Moribund shrimp analysed in this study did not show classical clinical signs linked to the presence of blue-green algae, such as necrosis of the midgut lining epithelium, resulting in hemocytic enteritis (Lightner, 1978).

While some pigments are unambiguous markers of some phytoplankton classes, many markers are present in several classes (Wright et al., 1996). Fucoxanthin, in our study the second dominant accessory pigment after zeaxanthin, is one of these, emphasizing the importance of Chromophytes, organisms that contain chlorophyll-c, in the pond samples. Fucoxanthin has already been reported as a dominant accessory pigment and is attributed to diatoms (Burford, 1997). In our study, TChl $a$-containing diatoms ranged from $3 \%$ to $57 \%$ of the total $\mathrm{Chl} a$ biomass. According to the literature, the Bacillariophyceae class constitutes one of the major and more diverse components of phytoplankton populations in shrimp ponds. In this environment, this class was reported to contain at least 42 genera in Thailand (Tookwinas and Songsangjinda, 1999), 35 genera in Australia (Stafford, 1999), 14 genera in Mexico (Cortés-Altamirano et al., 1995), 13 genera in Bangladesh (Islam et al., 2004) and 9 genera in Malaysia (Yusoff et al., 2002). Diatoms contributed to almost $70 \%$ of the species (51 species) number in Brazil (Casé et al., 2008). About 20 and 40 genera were identified in shrimp ponds and in coastal waters of New Caledonia, respectively (Unpublished data; Jacquet et al., 2006). Identification and enumeration were generally conducted using optical microscopy, which prevents any taxonomic identification of small-size nanophytoplankton species and thus leads to underestimation of the diversity of this group. In this study, 
phylogenetic analyses showed that Arcocellulus mammifer and Chaetoceros calcitrans were proportionally dominant in picoeukaryote populations. This is in agreement with previous results found in other New Caledonian shrimp ponds (Courties et al., 2005). During mortality outbreaks, one species of the genus Thalassiosira was also identified by scanning electron microscopy (SEM) in the same farm in March 2011 with an abundance reaching $15 \times 10^{3}$ cells $\mathrm{ml}^{-1}$, while one species of the genus Cyclotella was identified by SEM in another farm in April 2011 with abundance reaching $14 \times 10^{3}$ cells $\mathrm{ml}^{-1}$. The species Thalassiosira $c f$. pseudonana and the genera Cyclotella belonging to nanoplankton types 2 or 3 were previously identified by transmission electron microscope (TEM) and SEM in another shrimp farm located in the same bay (Courties et al., 2005).

Green algae are also one of the groups which dominate the phytoplankton community and are little described in the literature on shrimp aquaculture ecosystems. They largely belong to the pico and the small-sized nanophytoplankton. TChl $a$ contribution of green algae varied from 10 to $53 \%$. These populations were observed in light microscopy as tiny red, green and brown dots that were not taxonomically identifiable, leading to an underestimation of their diversity (Potter et al., 1997). Our results confirmed results obtained from a molecular approach based on 18S rRNA gene clone libraries conducted in 2004 on a sample collected in a New Caledonian shrimp pond (Courties et al., 2005). The clone libraries analysis revealed an assemblage of several classes of eukaryotic cells, including Prasinophyceae, which represented $26.8 \%$ of the sequences. Phylogeny and pigment analysis suggest that several species of Prasinophytes could be present in the pond ecosystem at the same time. Our results identified two groups among Prasinophyceae: the prasinoxanthin-containing and the prasinoxanthin-less Prasinophyceae (Egeland et al., 1997; Latasa et al., 2004), with clear dominance of the second group. Chl $a$-containing prasinoxanthin-less Prasinophyceae ranged from $10 \%$ to $48 \%$ of the total TChl $a$ biomass. A new species of the Mamiella genus was recently discovered and observed by transmission electron microscopy (TEM) from a 
sampling conducted at the same farm. Analysis of the pigments by HPLC of this cultured species showed that it belonged to Prasinophytes Type 3 (with prasinoxanthin). As regards the green algae in New Caledonian shrimp ponds, Courties et al. (2005) showed a significant abundance of the Trebouxiophyceae class (Chlorophyta) in the picophytoplankton fraction (15\% of the PEUK). This class could explain a part of the presence of lutein in our samples. The presence of Chl $b$ and diadinoxanthin together within the 2-20 $\mu \mathrm{m}$ size class fraction may also indicate the presence of Euglenophyceae. This class was already observed by optical microscope but at low abundance in ponds located in Asian countries (Yusoff et al., 2002; Islam et al., 2004; Cremen et al., 2007) and in Australia (Stafford, 1999).

Three minor algal groups, Haptophyceae, Cryptophyceae and Dinophyceae, were identified in our samples. The pigment analysis did not exclude the presence of two other groups: Pelagophyceae and Dictyochophyceae. The accessory pigment 19 'BF is the most characteristic pigment marker of Dictyochophyceae (silicoflagellates) (Eikrem et al., 2004; Edvardsen et al., 2007). Dictyochophyceae are widespread in marine waters and are mostly distributed in temperate and polar regions. They usually size between 20 and $100 \mu \mathrm{m}$ but have few small representatives within small-sized nanophytoplankton (Eikrem et al., 2004). Dictyocha fibula was the only microplanktonic species of this class identified in the bays of New Caledonia (Jacquet et al., 2006), while a bloom of naked nanoplanktonic Dictyophyceae was observed in an industrial farm during mortality outbreaks in July 2011 (Nézan, pers. com.). Pelagophytes are abundant in pico- and nano-phytoplankton and can cause harmful brown tides in littoral embayments with densities exceeding $10^{6}$ cells ml $^{-1}$ (Gobler et al., 2011) but, to our knowledge, this has never been described in environments such as shrimp ponds. As regards Cryptophytes, FCM signatures were characteristic of large cells emitting orange and red fluorescence due to biliprotein and chlorophyll pigments, respectively. Data from this study suggested that this group could comprise several species. In parallel, alloxanthin and $\alpha-$ carotene were detected together in the same samples and validated Cryptophyceae presence in 
this ecosystem. The genera Cryptomonas was previously reported in Australian shrimp ponds (Stafford, 1999).

As regards Haptophytes, the occurrence of 19 'HF carotenoid in almost all samples indicates the presence of this group (Zapata et al., 2004). The contribution of Haptophytes to Tchl $a$ was estimated to be less than $0.5 \%$. Several different size classes of Prymnesiophyceae (Haptophytes) were expected in some of our samples. Indeed, this class is abundant in tropical and subtropical regions as a major component of nano-plankton. Seventeen genera (coccolithophorides) were reported in the lagoon waters of New Caledonia (Jacquet et al., 2006). Only 60\% of the prymnesiophyte strains surveyed by Jeffrey and Wright (1994) contained the 19 'HF pigment. Zapata et al. (2004) proposed using eight different pigment types to discriminate the Haptophyte families. These eight types contain chl c2, MgDVP, fucoxanthin, diadinoxanthin and $\beta, \beta$-carotene pigments and were found in our samples. This study has also shown that types 6 and 7 contain 19'BF as trace and type 8 in significant concentrations. Phaeocystis sp. belongs to type 8 and was observed by SEM in a sample collected from New Caledonian shrimp ponds (Courties et al., 2005). The pigment composition showed the absence of chl C2-MGDG in our samples, suggesting the absence of type 7 (Zapata et al., 2001). Therefore, the occurrence of chl c3, 19'HF and 19'BF may be caused, not by only one, but by several species of Prymnesiophytes.

Peridin is an unequivocal marker of some photosynthetic dinoflagellates. Using CHEMTAX, a maximum of $2 \%$ of the TChl $a$ biomass in our study could be attributed to photosynthetic dinoflagellates. Caution should be observed when using only peridin as a dinoflagellates marker in field samples (Zapata et al., 2012). Major blooms of Karenia mikimotoi and Phaeocystis pouchetii were mistaken for diatom blooms on the basis of HPLC analysis (Irigoien et al., 2004). Several dinoflagellate genera such as Karenia and Karlodinium have been reported to have fucoxanthin as accessory pigment instead of peridin (Garcés et al., 2006). Moreover, peridin was not detected in shrimp ponds in Australia despite the relatively 
large numbers of dinoflagellates identified by optical microscopy (Burford, 1997). These heterotophic dinoflagellates are known to be effective grazers on diverse prey (e.g. Lim et al., 2014). Prorocentrum minimum and Scrippsiella trochoidea identified in shrimp ponds of New Caledonia and Australia were observed to feed on Cyanobacteria (Jeong et al., 2010). Thus, the grazing activity of dinoflagellates detected in both ponds $\mathrm{C}$ and $\mathrm{D}$, when the picocyanobacterial declines were observed, might explain the temporal variability of these procaryotic populations (Jeong et al., 2005). As regards species observed during shrimp mortalities in our study, Luciella masanensis was reported to be the cause of fish kills in farms located in Denmark (Moestrup et al., 2014). Massive dinoflagellate blooms of Prorocentrum rhathymun have already been associated with shrimp mortality outbreaks in New Caledonia and several other parts of the world (Alonso-Rodríguez and Páez-osuna, 2003). This species is an epibenthic dinoflagellate known to produce toxic compounds (Caillaud et al., 2010). K. veneficum associated with the toxins have been reported along the US Atlantic Coast and have been involved in fish kills (Hall et al., 2008). In the present study, there is no evidence that the algae identified as "potentially harmful for shrimp" are toxic or even stressful for reared animals. Further studies are needed to clarify this point. Culture of the organism should be initiated and used for possible toxicity testing and other biochemical and physiological studies. Their presence should be investigated and taken into account as a potential risk factor for vibriosis infection in future epidemiological studies. Moreover, because aquaculture ponds exchange with coastal environment, they are a potential source of microbial organisms dispersion cultivated in ponds, including potential harmful algae and pathogenic vibrios, towards coastal waters (Thomas et al., 2010). This exchange increases the risk of transmission of infectious diseases between hydrodynamically linked farms (Salama and Murray, 2011). Pond microbial dispersion poses also potential health threats for wild organisms through direct exposure to, or trophic transfer toxins (Lewitus et al., 2008). The ability of certain harmful algae species to produce and release chemicals that inhibit the 
growth of co-occurring phytoplankton has been already reported (Granémi et al., 2008). Future Investigations on the potential impact of shrimp effluents with such microbial communities on the receiving marine waters and particularly on the structure and functioning of the microbial ecosystem are also needed to progress into the impact of shrimp aquaculture effluents on coastal environment.

\section{Acknowledgements}

This work was supported by a research grant between the Loyalty Islands, Northern Province, Southern Province Government of New Caledonia and Institut Français de Recherche et d'Exploitation de la Mer (IFREMER) (12/1219969/C). We gratefully acknowledge the comments and suggestions of referees. We would like to thank José Herlin, Dominique Ansquer and Yannick Labreuche for their help with the pathogen surveys. We also thank the farmer who kindly helped us in this study.

\section{References}

Alonso-Rodríguez, R., Páez-osuna, F., 2003. Nutrients, phytoplankton and harmful algal blooms in shrimp ponds: a review with special reference to the situation in the Gulf of California. Aquaculture, 219, 317-336.

Andersen, R.A., Saunders, G.W., Paskind, M.P., Sexton, J.P., 1993. Ultrastructure and 18S RRNA gene sequence for Pelagomonas calceolata gen. et sp. Nov. and the descritption of a new algal class, the Pelagophyceae classis Nov.1. J. Phycol., 29, 701-715.

Auinger, B.M., Pfandl, K., Boenigk, J., 2008. Improved methodology for identification of protists and microalgae from plankton samples preserved in lugol's iodine solution: combining microscopic analysis with Single-Cell PCR. Appl. Environ. Microb., 74, 2505-2510.

Bouvier, T., Troussellier, M., Anzil, A., Courties, C., Servais, P., 2001. Using light scatter signal to estimate bacterial biovolume by flow cytometry. Cytometry, 44, 188-194.

Burford, M., 1997. Phytoplankton dynamics in shrimp ponds. Aquac. Res., 28, 351- 360.

Caillaud, A., de la Iglesia, P., Campàs, M., Elandaloussi, L., Fernández, M., Mohammad-Noor, N., Andree, K., Diogène, J., 2010. Evidence of okadaic acid production in a cultured strain of the marine dinoflagellate Prorocentrum rhathymum from Malaysia. Toxicon, 55, 633-637.

Casé M., Leça E.E., Leitão S.N., Sant'Anna E.E., Schwamborn R. and de Moraes Junior A.T., Plankton community as an indicator of water quality in tropical shrimp culture ponds, Mar. Pollut. Bull. 56, 2008, 1343-1352.

Cole, J.R., Wang, Q., Cardenas, E., Fish, J., Chai, B., Farris, R.J., Kulam-Syed-Mohideen, 
A.S., McGarrell, D.M., Marsh, T., Garrity, G.M., Tiedje, J.M., 2009. The Ribosomal Database Project: improved alignments and new tools for rRNA analysis. Nucleic Acids Res., 37, D141-D145.

Cortés-Altamirano, R., Páez-Osuna, F., Guerrero-Galván, S.R., Esparza-Leal, H.M., 1995. Variactión diurna del fitoplancton y los abióticos en un estanque camaronicola salobre en el sur de Sinaloa, México. Hidrobiológica, 5, 45-55.

Costa, R., Mermoud, I., Koblavi, S., Morlet, B., Haffner, P., Berthe, F., Le Groumellec, M., Grimont, P., 1998. Isolation and characterization of bacteria associated with a Penaeus stylirostris disease (Syndrome 93) in New Caledonia. Aquaculture, 164, 297-309.

Courties, C., Boeuf, G., 2004. Mesure en cytométrie en flux du picoplancton autotrophe et hétérotrophe: un outil de contrôle de la qualité des eaux des fermes d'élevage de crevettes. In: styli 2003. Trente ans de crevetticulture en Nouvelle-Calédonie. Ed. Ifremer, Actes Colloq., 38, pp. 150-157.

Courties, C., Lemonnier, H., Herbland, A., 2005. Structure et évolution des peuplements picoplanctoniques de bassins aquacoles mesurés en cytométrie en flux lors des deux syndromes en Nouvelle Calédonie. In: Book of Abstract of "Ecosystèmes et crevetticulture en Nouvelle-Calédonie" (22 - 24 juin 2005) (Ed. Ifremer), Nouméa.

Cremen, M.C.M., Martinez-Goss, M.R., Corre, Jr. V.L., Azanza, R.V., 2007. Phytoplankton bloom in commercial shrimp ponds using green-water technology. J Appl Phycol, 19, 615-624.

Descy, J.-P., Sarmento, H., Higgins, H.W., 2009. Variability of phytoplankton pigment ratios across aquatic environments. Eur. J. Phycol., 44, 319 - 330.

DiTullio, G.R., Geesey, M.E., Jones, D.R., Daly, K.L., Campbell, L., Smith, W.O., 2003. Phytoplankton assemblage structure and primary productivity along 170 degrees $\mathrm{W}$ in the South Pacific Ocean. Mar. Ecol. Prog. ser., 255, 55-80.

Edvardsen, B., Eikrem, W., Shalchian-Tabrizi, K., Riisberg, I., Johnsen, G., Naustvoll, L., Throndsen, J., 2007. Verrucophora farcimen gen. et sp. nov. (Dictyochophyceae, Heterokonta) a bloom-forming ichthyotoxic flagellate from the Skagerrak, Norway 1. J. Phycol., 43, 1054-1070.

Egeland, E.S., Guillard, R.R.L., Liaaen-Jensen, S. 1997. Additional carotenoid prototype representatives and a general chemosystematic evaluation of carotenoids in prasinophyceae (chlorophyta). Phytochemistry, 44, 1087-1097.

Eikrem, W., Romari, K., Latasa, M., Gall, F.L., Throndsen, J., Vaulot, D., 2004. Florenciella parvula gen. et sp. nov. (Dictyochophyceae, Heterokontophyta), a small flagellate isolated from the English Channel. Phycologia, 43, 658-668.

Flegel, T.W., 2012. Historic emergence, impact and current status of shrimp pathogens in Asia. J. Invertebr. Pathol., 110, 166-173.

Frazão, B., Martins, R., Vasconcelos, V., 2010. Are known cyanotoxins involved in the toxicity of picoplanktonic and filamentous North Atlantic marine cyanobacteria? Mar. Drugs, 8, 1908-1919.

Gárate-Lizárraga, I., Band-Schmidt, C.J., López-Cortés, D.J., del Socorro Muñetón-Gómez, M. 2009. Bloom of Scrippsiella trochoidea (Gonyaulacaceae) in a shrimp pond in the southwestern Gulf of California, Mexico. Mar. Pollut. Bull., 58, 145-149.

Garcés, E., Fernandez, M., Penna, A., Van Lenning, K., Gutierrez, A., Camp, J., Zapata, M., 2006. Characterization of NW Mediterranean Karlodinium spp. (Dinophyceae) strains using morphological, molecular, chemical, and physiological methodologies. J. Phycol., 42, 1096-1112.

Gin, K.Y.H., Zhang, S., Lee, Y.K., 2003. Phytoplankton community structure in Singapore's coastal waters using HPLC pigment analysis and flow cytometry. J. Plankton Res., 25, 1507-1519.

Goarant, C., Merien, F., 2006. Quantification of Vibrio penaeicida, the etiological agent of 
Syndrome 93 in New Caledonian shrimp, by real-time PCR using SYBR Green I chemistry. J. Microbiol. Meth, 67, 27-35.

Goarant, C., Merien, F., Berthe, F., Mermoud, I., Perolat, P., 1999. Arbitrarily primed PCR to type Vibrio spp. pathogenic for shrimp. Appl. Environ. Microb., 65, 1145-1151.

Goarant, C., Ansquer, D., Herlin, J., Domalain, D., Imbert, F., De Decker, S., 2006a. "Summer Syndrome" in Litopenaeus stylirostris in New Caledonia: pathology and epidemiology of the etiological agent, Vibrio nigripulchritudo. Aquaculture, 253, 105-113.

Goarant, C., Reynaud, Y., Ansquer, D., de Decker, S., Saulnier, D., le Roux, F., 2006b. Molecular epidemiology of Vibrio nigripulchritudo, a pathogen of cultured penaeid shrimp (Litopenaeus stylirostris) in New Caledonia. Syst. Appl. Microbiol., 29, 570-580.

Goarant, C., Reynaud, Y., Ansquer, D., de Decker, S., Merien, F., 2007. Sequence polymorphism- based identification and quantification of Vibrio nigripulchritudo at the species and subspecies level targeting an emerging pathogen for cultured shrimp in New Caledonia. J. Microbiol. Meth., 70, 30-38.

Gobler, C.J., Berry, D.L., Dyhrman, S.T., Wilhelm, S.W., Salamov, A., Lobanov, A.V., Zhang, Y., Collier, J.L., Wurch, L.L., Kustka, A.B., Dill, B.D., Shah, M., VerBerkmoes, N.C., Kuo, A., Terry, A., Pangilinan, J., Lindquist, E.A., Lucas, S., Paulsen, I.T., HattenrathLehmann, T.K., Talmage, S.C., Walker, E.A., Koch, F., Burson, A.M., Marcoval, M.A., Tang, Y.-Z., LeCleir, G.R., Coyne, K.J., Berg, G.M., Bertrand, E.M., Saito, M.A., Gladyshev, V.N., Grigoriev, I.V., 2011. Niche of harmful alga Aureococcus anophagefferens revealed through ecogenomics. PNAS, 108, 4352-4357.

Goudenège, D., Labreuche, Y., Krin, E., Ansquer, D., Mangenot, S., Calteau, A., Médigue, C., Mazel, D., Pol, M.F., Le Roux, F., 2013. Comparative genomics of pathogenic lineages of Vibrio nigripulchritudo identifies virulence associated traits. The ISME Journal, 1-12.

Granéli, E., Weberg, M., Salomon, P.S., 2008. Harmful algal blooms of allelopathic microalgal species: the role of eutrophication. Harmful Algae, 8, 94-102.

Guillebault, D., Laghdass, M., Catala, P., Obernosterer, I., Lebaron, P., 2010. Improved method for bacterial cell capture after flow cytometry cell sorting. Appl. Environ. Microb, 76, 7352-7355.

Hall, N., Litaker, R.W., Fensin, E., Adolf, J., Bowers, H., Place, A., Paerl, H., 2008. Environmental factors contributing to the development and demise of a toxic dinoflagellate (Karlodinium veneficum) bloom in a shallow, eutrophic, lagoonal estuary. Estuaries Coasts, 31, 402-418.

Higgins, H.W., Mackey, D.J., 2000. Algal class abundances, estimated from chlorophyll and carotenoid pigments, in the western Equatorial Pacific under El Nino and non-El Nino conditions. Deep Sea Res. Pt 1, 47, 1461- 1483.

Higgins, H.W., Mackey, D.J., Clementson, L., 2006. Phytoplankton distribution in the Bismarck Sea north of Papua New Guinea: the effect of the Sepik River outflow. Deep Sea Res. Pt 1, 53, 1845-1863.

Higgins, H.W., Wright, S.W., Schlüter, L., 2011. Quantitative interpretation of chematoxonomic pigments data. In: Phytoplankton Pigments - Characterization, Chemotaxonomy and Applications in Oceanography (Eds. by S. Roy CL, E.S. Egeland, G. Johnsen). Cambridge University Press,, Cambridge pp. 257-313.

Holm-Hansen, O., Lorenzen, C.J., Holmes, R.W., Strickland, J.D.H., 1965. Fluorometric determination of chlorophyll. ICES J. Mar. Sci., 30, 3-15.

Irigoien, X., Meyer, B., Harris, R., Harbour, D., 2004. Using HPLC pigment analysis to investigate phytoplankton taxonomy: the importance of knowing your species. Helgol. Mar. Res., 58, 77-82.

Islam, M.S., Sarker, M.J., Yamamoto, T., Wahab, M.A., Tanaka, M., 2004. Water and sediment quality, partial mass budget and effluent $\mathrm{N}$ loading in coastal brackishwater shrimp farms in Bangladesh. Mar. Pollut. Bull., 48, 471-485. 
Jacquet, S., Delesalle, B., Torréton, J.-P., Blanchot, A., 2006. Responses of the phytoplankton communities to increased anthropogenic influences (Southwestern Lagoon, New Caledonia). Mar. Ecol. Prog. Ser., 320, 65-78.

Jeffrey, S.W., Wright, S.W., 1994. Photosynthetic pigments in the Haptophyta. In: Green J.C. and Leadbeater B.S.C. (Eds), the Haptophyte Algae, Clarendon Press, Oxford, pp. 111132.

Jeffrey, S.W., Wright, S.W., 1997. Qualitative and quantitative HPLC analysis of SCOR reference algal cultures. In: Jeffrey S.W., Mantoura R.F.C., and Wright S.W. (Eds), Phytoplankton Pigments in Oceanography: Guidelines to Modern Methods, UNESCO Publishing, Paris, pp. 343-360.

Jeffrey, S.W., Mantoura R.F.C., Wright S.W., 1997. Phytoplankton Pigments in Oceanography: Guidelines to Modern Methods. UNESCO Publishing, Paris, pp. 661.

Jeffrey, S.W., Wright, S.W., Zapata, M., 2011. Phytoplankton Pigments: Characterization, Chemotaxonomy and Applications in Oceanography. In Roy, S., Llewellyn C.A., Egeland E.S and Johnsen G. (Eds), Microalgal classes and their Signature Pigments, 2011, Cambridge University Press, United Kingdom, pp. 3-77.

Jeong, H.J., Park, J.Y., Nho, J.H., Park, M.O., Ha, J.H., Seong, K.A., Jeng, C., Seong, C.N., Lee, K.Y., Yih, W.H., 2005. Feeding by red-tide dinoflagellates on the cyanobacterium Synechococcus. Aquat. Microb. Ecol., 41, 131-143.

Jeong, H., Yoo, Y., Kim, J., Seong, K., Kang, N., Kim, T., 2010. Growth, feeding and ecological roles of the mixotrophic and heterotrophic dinoflagellates in marine planktonic food webs. Ocean Sci J., 45, 65-91.

Kautsky, N., Rönnbäck, P., Tedengren, M., Troell, M., 2000. Ecosystem perspectives on management of disease in shrimp pond farming. Aquaculture, 191, 145-161.

Klepac-Ceraj, V., Ceraj, I., Polz, M.F., 2006. Clusterer: extendable java application for sequence grouping and cluster analyses. Online J. Bioinform. 7:15-21

Latasa, M., Scharek, R., Gall, F.L., Guillou, L., 2004. Pigment suites and taxonomic groups in Prasinophyceae. J Phycol., 40, 1149-1155.

Laviale, M., Neveux, J., 2011. Relationships between pigment ratios and growth irradiance in 11 marine phytoplankton species. Mar. Ecol. Prog. ser., 425, 63-77.

Le Roux, F., Labreuche, Y., Davis, B.M., Iqbal, N., Mangenot, S., Goarant, C., Mazel, D., Waldor, M.K., 2010. Virulence of an emerging pathogenic lineage of Vibrio nigripulchritudo is dependent on two plasmids. Environ. Microbiol., 13, 296-306.

Lemonnier, H., 2007. Effet des conditions environnementales sur le développement des pathologies à Vibrio dans les élevages de crevettes en Nouvelle-Calédonie. Université de La Rochelle, La Rochelle, pp. 274 p. (http://archimer.ifremer.fr/doc/00000/2643/)

Lemonnier, H., Herbland, A., Salery, L., Soulard, B., 2006. "Summer syndrome" in Litopenaeus stylirostris grow out ponds in New Caledonia: Zootechnical and environmental factors. Aquaculture, 261, 1039-1047.

Lemonnier, H., Courties, C., Mugnier, C., Torréton, J.-P., Herbland, A., 2010. Nutrient and microbial dynamics in eutrophying shrimp ponds affected or unaffected by vibriosis. Mar. Pollut. Bull., 60, 402-411.

Lewitus, A.J., Brock, L.M., Burke, M.K., DeMattio, K.A., Wilde, S.B., 2008. Lagoonal stormwater detention ponds as promoters of harmful algal blooms and eutrophication along the South Carolina coast. Harmful Algae, 8, 60-65.

Lightner, D.V., 1978. Possible toxic effects of the marine blue-green alga, Spirulina subsalsa, on the blue shrimp, Penaeus stylirostris. J. Invertebr. Pathol., 32, 139-150.

Lim, A.S., Jeong, H.J., Jang, T.Y., Yoo, Y.D., Kang, N.S., Yoon, E.Y., Kim, G.H., 2014. Feeding by the newly described heterotrophic dinoflagellate Stoeckeria changwonensis: a comparison with other species in the family Pfiesteriaceae. Harmful Algae, 36, 11-21.

Lucas, R., Courties, C., Herbland, A., Goulletquer, P., Marteau, A.L., Lemonnier, H., 2010. 
Eutrophication in a tropical pond: understanding the bacterioplankton and phytoplankton dynamics during a vibriosis outbreak using flow cytometric analyses. Aquaculture, 310, $112-121$.

Mackey, M., Mackey, D., Higgins, H., Wright, S., 1996. CHEMTAX - a program for estimating class abundances from chemical markers: application to HPLC measurements of phytoplankton. Mar. Ecol. Prog. ser., 144, 265-283.

Martins, R., Fernandez, N., Beiras, R., Vasconcelos, V., 2007. Toxicity assessment of crude and partially purified extracts of marine Synechocystis and Synechococcus cyanobacterial strains in marine invertebrates. Toxicon, 50, 791-799.

Mermoud, I., Costa, R., Ferré, O., Goarant, C., Haffner, P., 1998. Syndrome 93 in New Caledonian outdoor rearing ponds of Penaeus stylirostris: history and description of the three major outbreaks. Aquaculture, 164, 323-335.

Moestrup Ø, Hansen G., Daugbjerg N., Lundholm N., Overton J., Vestergård, M., Steenfeldt S.J., Calado A.J., Hansen, P.J., 2014. The dinoflagellates Pfiesteria shumwayae and Luciella masanensis cause fish kills in recirculation fish farms in Denmark. Harmful Algae, 32, 33-39.

Mugnier, C., Justou, C., Lemonnier, H., Patrois, J., Ansquer, D., Goarant, C., Lecoz J.-R., 2013. Biological, physiological, immunological and nutritional assessment of farmreared Litopenaeus stylirostris shrimp affected or unaffected by vibriosis. Aquaculture, 388-391, 105-114.

Paerl, H.W., Valdes, L.M., Pinckney, J.L., Piehler, M.F., Dyble, J., Moisander, P.H., 2003. Phytoplankton photopigments as indicators of estuarine and coastal eutrophication. BioScience, 53, 953-964.

Potter, D., Lajeunesse, T.C., Saunders, G.W., Anderson, R.A., 1997. Convergent evolution masks extensive biodiversity among marine coccoid picoplankton. Biodivers. Conserv., 6, 99-107.

Pruesse, E., Quast, C., Knittel, K., Fuchs, B.M., Ludwig, W., Peplies, J., Glöckner, F.O., 2007. SILVA: a comprehensive online resource for quality checked and aligned ribosomal RNA sequence data compatible with ARB. Nucleic Acids Res., 35, 7188-7196.

Reynaud, Y., Saulnier, D., Mazel, D., Goarant, C., Le Roux, F., 2008. Correlation between detection of a plasmid and high-level virulence of Vibrio nigripulchritudo, a pathogen of the shrimp Litopenaeus stylirostris. Appl. Environ. Microb, 74, 3038-3047.

Salama, N.K.G., Murray, A.G., 2011. Farm size as a factor in hydrodynamic transmission of pathogens in aquaculture fish production. Aquacult. Environ. Interact., 2, 61-74.

Saulnier, D., Haffner, P., Goarant, C., Levy, P., Ansquer, D., 2000. Experimental infection models for shrimp vibriosis studies: a review. Aquaculture, 191, 133-144.

Schlüter, L., Henriksen, P., Nielsen, T.G., Jakobsen, H.H., 2011. Phytoplankton composition and biomass across the southern Indian Ocean. Deep Sea Res. Pt 1, 58, 546-556.

Stackebrandt, E., Ebers,J., 2006. Taxonomic parameters revisited: tarnished gold standards Microbiol. Today, 33, 152-155.

Stafford, C., 1999. A guide to phytoplankton of aquaculture ponds. Queensland Department of Primary Industries Information Series, Q199011, pp. 59.

Stentiford, G.D., Neil, D.M., Peeler, E.J., Shields, J.D., Small, H.J., Flegel, T.W., Vlak, J.M., Jones, B., Morado, F., Moss, S., Lotz, J., Bartholomay, L., Behringer, D.C., Hauton, C., Lightner, D.V., 2012. Disease will limit future food supply from the global crustacean fishery and aquaculture sectors. J. Invertebr. Pathol., 110, 141-157.

Thomas, Y., Courties, C., El Helwe, Y., Herbland, A., Lemonnier, H., 2010. Spatial and temporal extension of eutrophication associated with shrimp farm wastewater discharges in the New Caledonian Lagoon. Mar. Pollut. Bull., 61, 387-398.

Tookwinas, S., Songsangjinda, P., 1999. Water quality and phytoplankton communities in intensive shrimp culture ponds in Kung Krabaen Bay, Earstern Thailand. J. World 
Aquacult. Soc., 30, 36-45.

Tran, L., Nunan, L., Redman, R.M., Mohney, L.L., Pantoja, C.R., Fitzsimmons, K., Lightner, D.V., 2013. Determination of the infectious nature of the agent of acute hepatopancreatic necrosis syndrome affecting penaeid shrimp. Dis. Aquat. Organ., 105, 45- 55.

Troussellier, M., Courties, C., Vaquer, A., 1993. Recent applications of flow cytometry in aquatic microbial ecology. Biology of the Cell, 78, 111-121.

Vaulot, D., Courties, C., Partensky, F., 1989. A simple method to preserve oceanic phytoplankton for flow cytometric analyses. Cytometry, 10, 629-635.

Wright, S., Thomas, D., Marchant, H., Higgins, H., Mackey, M., Mackey, D., 1996. Analysis of phytoplankton of the Australian sector of the Southern Ocean: comparisons of microscopy and size frequency data with interpretations of pigment HPLC data using the I'CHEMTAXI' matrix factorisation program. Mar. Ecol. Prog. ser., 144, 285-298.

Yusoff, F.M., Zubaidah, M.S., Matias, H.B., Kwan, T.S., 2002. Phytoplankton succession in intensive marine shrimp culture pond treated with a commercial bacterial product. Aquac. Res., 33, 269-278.

Zapata, M., Rodriguez, F., Garrido, J., 2000. Separation of chlorophylls and carotenoids from marine phytoplankton: a new HPLC method using a reversed phase C_8 column and pyridine-containing mobile phases. Mar. Ecol. Prog. ser., 195, 29-45.

Zapata, M., Edvardsen, B., Rodríguez, F., Maestro, M.Â., Garrido, J.L., 2001. Chlorophyll c2 monogalactosyldiacylglyceride ester (chl c2-MGDG). A novel marker pigment for Chrysochromulina species (Haptophyta). Mar. Ecol. Prog. ser., 219, 85-98.

Zapata, M., Jeffrey, S.W., Wright, S.W., Rodríguez, F., Garrido, J.L., Clementson, L., 2004. Photosynthetic pigments in 37 species (65 strains) of Haptophyta: implications for oceanography and chemotaxonomy. Mar. Ecol. Prog. ser., 270, 83-102.

Zapata, M., Fraga, S., Rodríguez, F., Garrido, J., 2012. Pigment-based chloroplast types in dinoflagellates. Mar. Ecol. Prog. ser., 465, 33-52.

Zhang, D., Wang, X., Xiong, J., Zhu, J., Wang, Y., Zhao, Q., Chen, H., Guo, A., Wu, J., Dai, H., 2014. Bacterioplankton assemblages as biological indicators of shrimp health status. Ecol. Indic., 38, 218-224. 
Table 1: Initial CHEMTAX pigment ratios for each taxonomic group. All ratio are normalized to Chlorophyll $a$.

\begin{tabular}{|c|c|c|c|c|c|c|c|c|c|c|c|c|c|c|}
\hline Class / Pigment & Chl c3 & Chl c2 & Chl c1 & PERI & BUT & FUCO & HEX & NEO & PRAS & VIOLA & ALLO & LUT & ZEA & Tchl $b$ \\
\hline Prasinophytes type 3 & 0 & 0 & 0 & 0 & 0 & 0 & 0 & 0.15525 & 0.33025 & 0.0745 & 0 & 0.022 & 0.11 & 0.8055 \\
\hline Prasinophytes type 1-2 & 0 & 0 & 0 & 0 & 0 & 0 & 0 & 0.05075 & 0 & 0.07525 & 0 & 0.0895 & 0.05525 & 0.654 \\
\hline Chlorophytes & 0 & 0 & 0 & 0 & 0 & 0 & 0 & 0.06475 & 0 & 0.06925 & 0 & 0.33425 & 0.0645 & 0.35425 \\
\hline Dinophytes & 0 & 0.2755 & 0 & 0.66275 & 0 & 0 & 0.095 & 0 & 0 & 0 & 0 & 0 & 0 & 0 \\
\hline Cryptophytes & 0 & 0.11475 & 0 & 0 & 0 & 0 & 0 & 0 & 0 & 0 & 0.18675 & 0 & 0 & 0 \\
\hline Haptophytes type 6 & 0.161 & 0.188 & 0 & 0 & 0.01 & 0.212 & 0.842 & 0 & 0 & 0 & 0 & 0 & 0 & 0 \\
\hline Pelagophytes & 0.244 & 0.2015 & 0 & 0 & 0.012 & 0.2465 & 1.1255 & 0 & 0 & 0 & 0 & 0 & 0 & 0 \\
\hline Cyanophytes & 0 & 0 & 0 & 0 & 0 & 0 & 0 & 0 & 0 & 0 & 0 & 0 & 1.167 & 0 \\
\hline Diatoms & 0 & 0.1305 & 0.02075 & 0 & 0 & 0.616 & 0 & 0 & 0 & 0 & 0 & 0 & 0 & 0 \\
\hline
\end{tabular}


Table 2. Total number of $16 \mathrm{~S}$ and $18 \mathrm{~S}$ ribosomal RNA gene sequences obtained by pyrosequencing from two groups of cells (UNK and PEUK) sorted by FCM.

\begin{tabular}{lccccc}
\hline \multicolumn{1}{c}{$16 \mathrm{~S}$} & \multicolumn{3}{c}{$18 \mathrm{~S}$} \\
\hline & $\begin{array}{c}\text { Procaryota } \\
\text { domain }\end{array}$ & $\begin{array}{c}\text { Other } \\
\text { eukaryota }\end{array}$ & $\begin{array}{c}\text { Plantae } \\
\text { kingdom }\end{array}$ & $\begin{array}{c}\text { Animalia } \\
\text { kingdom }\end{array}$ & Fungi kingdom \\
\hline UNK & 4063 & 529 & 4 & 13 & 14 \\
PEUKs & 443 & 4294 & 68 & 15 & 1 \\
\hline
\end{tabular}


Table 3. Number of $18 \mathrm{~S}$ ribosomal RNA gene sequences obtained for each population sorted by FCM.

Only the algae sequences are presented.

\begin{tabular}{|c|c|c|c|c|c|c|}
\hline Domain or Kingdom & Phylum & Class & order & Family & UNK & Picoeukaryote \\
\hline $\begin{array}{l}\text { Plantae kingdom } \\
\text {. }\end{array}$ & Streptophyta & Liliopsida & Dioscoreales & Burmanniaceae & 3 & 0 \\
\hline Plantae kingdom & $\begin{array}{l}\text { Klebsormidiophyceae:: } \\
\text { Streptophyta }\end{array}$ & $\begin{array}{l}\text { Klebsormidiophyceae } \\
\text { (class)::Streptophyta (class) }\end{array}$ & $\begin{array}{l}\text { Klebsormidiophyceae } \\
\text { (order)::Klebsormidiales }\end{array}$ & $\begin{array}{c}\text { Klebsormidiophyceae } \\
\text { (family):: Klebsormidiaceae }\end{array}$ & 1 & 0 \\
\hline $\begin{array}{l}\text { Plantae kingdom } \\
\text { Plantae kingdom }\end{array}$ & Chlorophyta & Chlorophyta (class) & $\begin{array}{c}\text { Mamiellales } \\
\text { Chlorophyta (order) }\end{array}$ & $\begin{array}{l}\text { Mamiellales (family) } \\
\text { Chlorophyta (family) }\end{array}$ & $\begin{array}{l}0 \\
0\end{array}$ & $\begin{array}{c}63 \\
3\end{array}$ \\
\hline Plantae kingdom & & & $\begin{array}{c}\text { Mamiellales: } \\
\text { Pseudoscourfieldiales }\end{array}$ & $\begin{array}{c}\text { Mamiellales } \\
\text { (family)::Pycnococcaceae }\end{array}$ & 0 & 2 \\
\hline $\begin{array}{l}\text { Eukaryota domain } \\
\text { Eukaryota domain } \\
\text { Eukaryota domain } \\
\text { Eukaryota domain }\end{array}$ & Bacillariophyta & Coscinodiscophyceae & $\begin{array}{l}\text { Chaetocerotales } \\
\text { Cymatosirales } \\
\text { Lithodesmidales } \\
\text { Thalassiosirales }\end{array}$ & $\begin{array}{l}\text { Chaetocerotaceae } \\
\text { Cymatosiraceae } \\
\text { Lithodesmiaceae } \\
\text { Thalassiosiraceae }\end{array}$ & $\begin{array}{c}2 \\
95 \\
3 \\
1\end{array}$ & $\begin{array}{c}2212 \\
1795 \\
6 \\
3\end{array}$ \\
\hline Eukaryota domain & & & $\begin{array}{c}\text { Cymatosirales::Thalassi } \\
\text { osirales } \\
\text { Chaetocerotales:: }\end{array}$ & $\begin{array}{l}\text { Cymatosiraceae:: } \\
\text { Thalassiosiraceae } \\
\text { Chaetocerotaceae:: }\end{array}$ & 0 & 1 \\
\hline Eukaryota domain & & & $\begin{array}{l}\text { Lithodesmidales:: } \\
\text { Cymatosirales }\end{array}$ & $\begin{array}{l}\text { Lithodesmiaceae:: } \\
\text { Cymatosiraceae }\end{array}$ & 0 & 1 \\
\hline Eukaryota domain & & & $\begin{array}{c}\text { Chaetocerotales::Lithod } \\
\text { esmidales }\end{array}$ & $\begin{array}{l}\text { Chaetocerotaceae:: } \\
\text { Lithodesmiaceae }\end{array}$ & 0 & 9 \\
\hline Eukaryota domain & & & Rhizosoleniales & Rhizosoleniaceae & 0 & 1 \\
\hline Eukaryota domain & & & $\begin{array}{l}\text { Fragilariophyceae } \\
\text { (order)::Cymbellales }\end{array}$ & $\begin{array}{l}\text { Fragilariaceae:: } \\
\text { Cymbellaceae }\end{array}$ & 0 & 1 \\
\hline Eukaryota domain & & & Eupodiscales & Eupodiscaceae & 0 & 1 \\
\hline Eukaryota domain & & & $\begin{array}{c}\text { Bacillariales::Hemiaulale } \\
\mathrm{s}\end{array}$ & $\begin{array}{c}\text { Fragilariophyceae } \\
\text { (family)::Bacillariaceae }\end{array}$ & 0 & 1 \\
\hline Eukaryota domain & & & $\begin{array}{c}\text { Hemiaulales::Bacillariale } \\
\text { s }\end{array}$ & $\begin{array}{c}\text { Fragilariophyceae } \\
\text { (family)::Cymbellaceae }\end{array}$ & 0 & 1 \\
\hline Eukaryota domain & & Fragilariophyceae & Fragilariales & Fragilariaceae & 0 & 90 \\
\hline Eukaryota domain & & & $\begin{array}{l}\text { Fragilariophyceae } \\
\text { (order) }\end{array}$ & $\begin{array}{l}\text { Fragilariophyceae } \\
\text { (family) }\end{array}$ & 0 & 105 \\
\hline Eukaryota domain & & & Striatellales & Striatellaceae & 1 & 3 \\
\hline Eukaryota domain & & $\begin{array}{l}\text { Coscinodiscophyceae:: } \\
\text { Fragilariophyceae }\end{array}$ & $\begin{array}{c}\text { Chaetocerotales::Fragila } \\
\text { riales }\end{array}$ & $\begin{array}{l}\text { Chaetocerotaceae:: } \\
\text { Fragilariaceae }\end{array}$ & 0 & 1 \\
\hline Eukaryota domain & & & $\begin{array}{c}\text { Chaetocerotales::Striatel } \\
\text { lales }\end{array}$ & $\begin{array}{l}\text { Chaetocerotaceae:: } \\
\text { Striatellaceae }\end{array}$ & 0 & 8 \\
\hline Eukaryota domain & & & $\begin{array}{c}\text { Cymatosirales::Striatellal } \\
\text { es }\end{array}$ & $\begin{array}{l}\text { Cymatosiraceae:: } \\
\text { Striatellaceae }\end{array}$ & 0 & 8 \\
\hline Eukaryota domain & & Bacillariophyceae & Bacillariales & Bacillariaceae & 0 & 2 \\
\hline Eukaryota domain & & & Cymbellales & Cymbellaceae & 0 & 7 \\
\hline Eukaryota domain & & & Achnanthales & Achnanthaceae & 0 & 18 \\
\hline Eukaryota domain & & $\begin{array}{l}\text { Bacillariophyceae:: } \\
\text { Coscinodiscophyceae }\end{array}$ & $\begin{array}{l}\text { Fragilariales:: } \\
\text { Cymbellales }\end{array}$ & $\begin{array}{l}\text { Bacillariaceae:: } \\
\text { Bellerocheaceae }\end{array}$ & 0 & 1 \\
\hline Eukaryota domain & & $\begin{array}{l}\text { Fragilariophyceae:: } \\
\text { Bacillariophyceae }\end{array}$ & Hemiaulales & Bellerocheaceae & 0 & 3 \\
\hline Eukaryota domain & & $\begin{array}{l}\text { Coscinodiscophyceae:: } \\
\text { Bacillariophyceae }\end{array}$ & $\begin{array}{l}\text { Fragilariophyceae } \\
\text { (order)::Bacillariales }\end{array}$ & $\begin{array}{l}\text { Bellerocheaceae:: } \\
\text { Bacillariaceae }\end{array}$ & 0 & 1 \\
\hline Eukaryota domain & & $\begin{array}{l}\text { Fragilariophyceae:: } \\
\text { Coscinodiscophyceae: } \\
\text { Bacillariophyceae }\end{array}$ & $\begin{array}{l}\text { Fragilariales:: } \\
\text { Thalassiosirales:: } \\
\text { Cymatosirales:: } \\
\text { Cymbellales } \\
\text { Fragilariales:: }\end{array}$ & $\begin{array}{c}\text { Fragilariaceae::Skeletonem } \\
\text { ataceae::Cymatosiraceae:: } \\
\text { Cymbellaceae } \\
\text { Fragilariaceae:: }\end{array}$ & 2 & 0 \\
\hline Eukaryota domain & & & $\begin{array}{l}\text { Chaetocerotales:: } \\
\text { Bacillariales }\end{array}$ & $\begin{array}{c}\text { Chaetocerotaceae:: } \\
\text { Bacillariaceae }\end{array}$ & 0 & 1 \\
\hline Eukaryota domain & Chrysophyceae & Chromulinales & Chromulinaceae & Chromulinaceae (family) & 10 & 0 \\
\hline Eukaryota domain & $\begin{array}{l}\text { Chrysophyceae:: } \\
\text { Synurophyceae }\end{array}$ & Chromulinales::Ochromonadales & $\begin{array}{c}\text { Chromulinaceae:: } \\
\text { Ochromonadales (order) }\end{array}$ & $\begin{array}{l}\text { Chromulinaceae } \\
\text { (family)::Ochromonadales } \\
\text { (family) }\end{array}$ & 4 & 9 \\
\hline Eukaryota domain & Raphidophyceae & Raphidophyceae (class) & Raphidophyceae (order) & Raphidophyceae (family) & 0 & 1 \\
\hline Eukaryota domain & Rhodophyta & Bangiophyceae & Porphyridiales & Phragmonemataceae & 1 & 0 \\
\hline Eukaryota domain & Synurophyceae & Ochromonadales & Ochromonadales (order) & Ochromonadales (family) & 0 & 1 \\
\hline
\end{tabular}




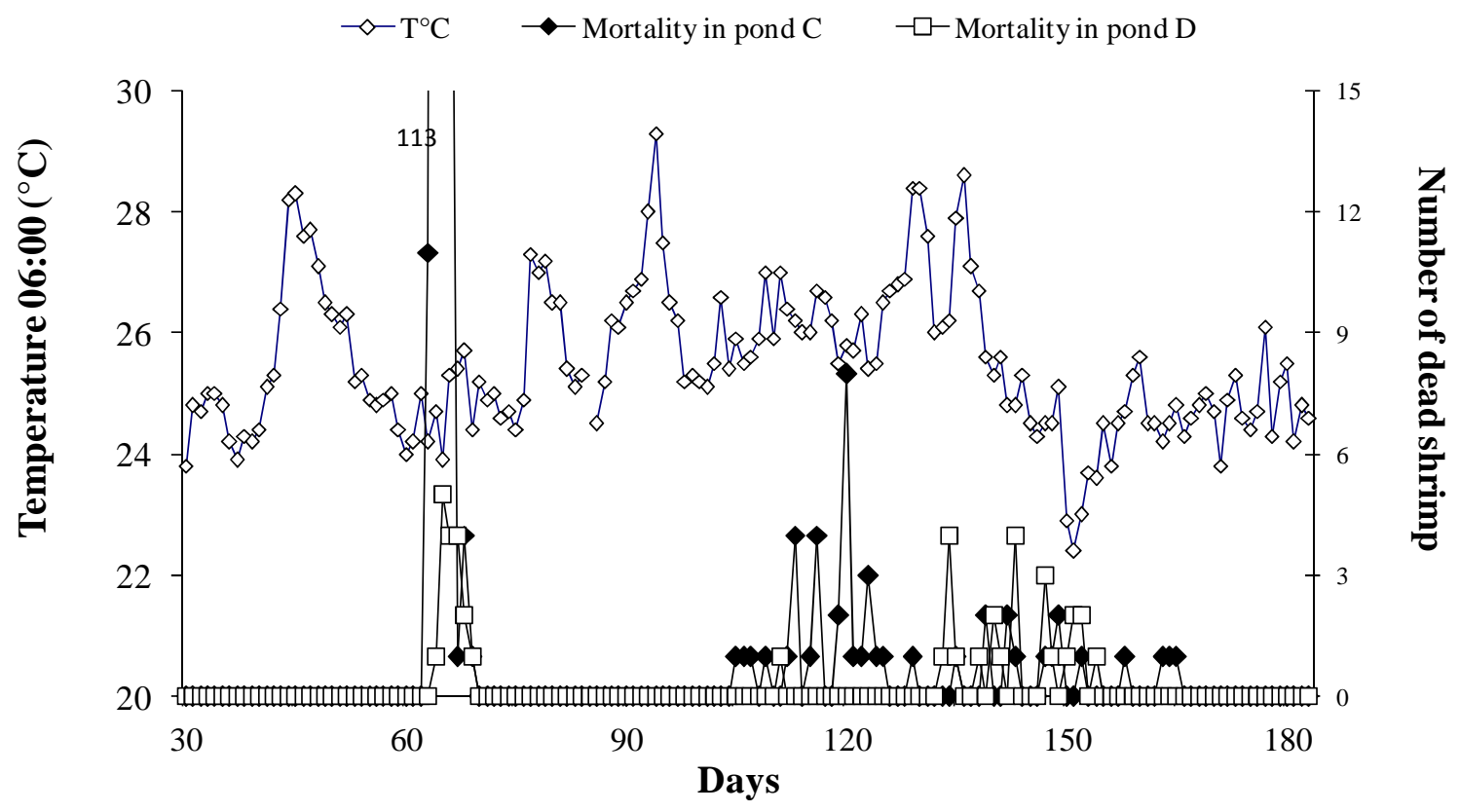

Fig. 1. Daily mean water temperature in the two ponds and number of dead shrimp counted on the pond edges of the two ponds (Ponds $C$ and $D$ ). 


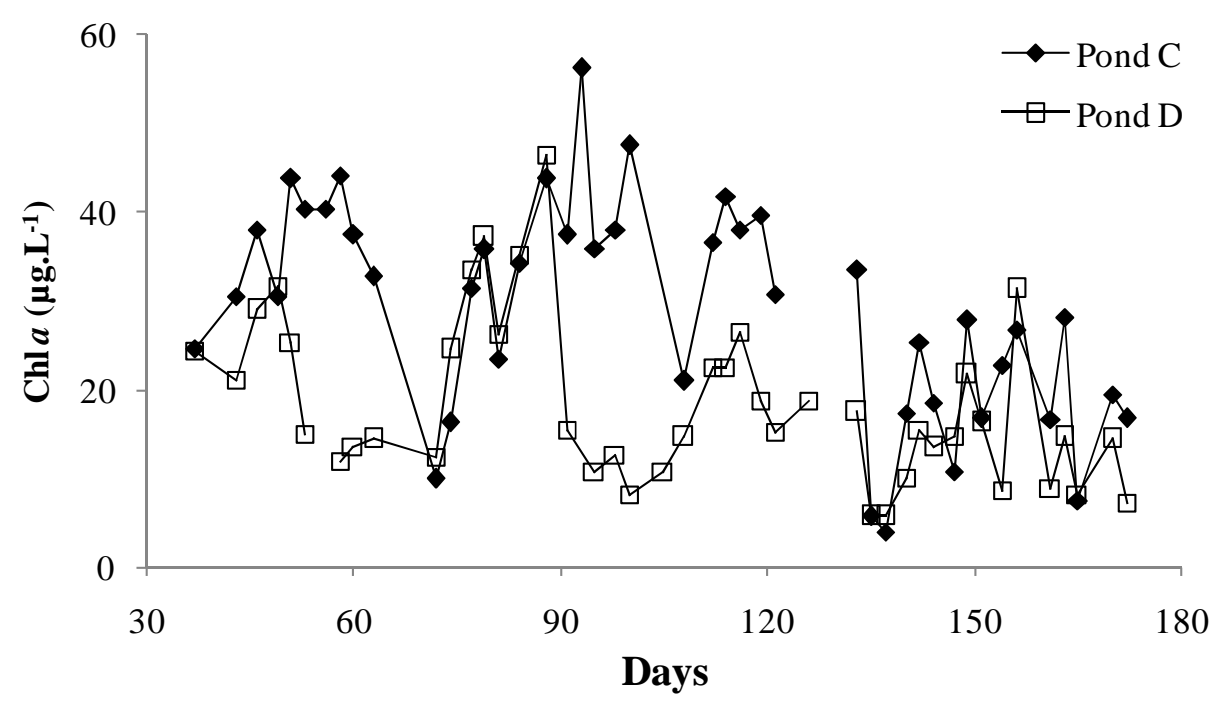

Fig. 2. Temporal variation of Chlorophyll $a$ concentration in the two ponds (Ponds C and D). 
a

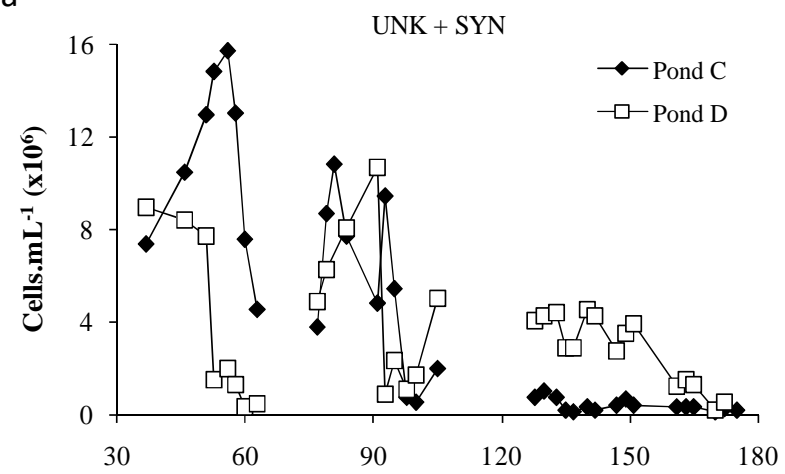

C

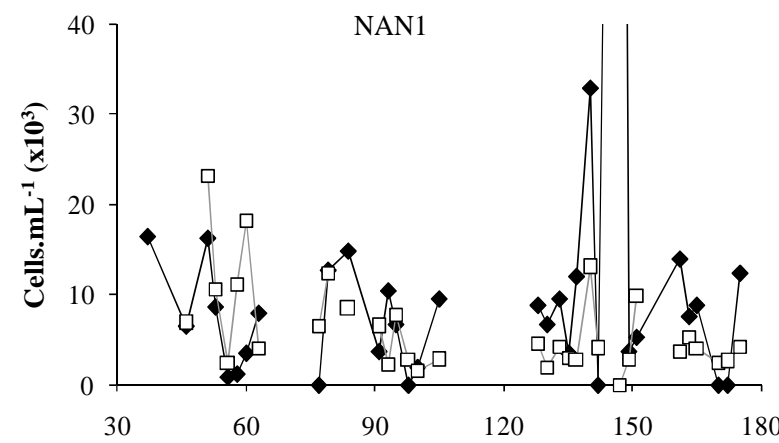

e

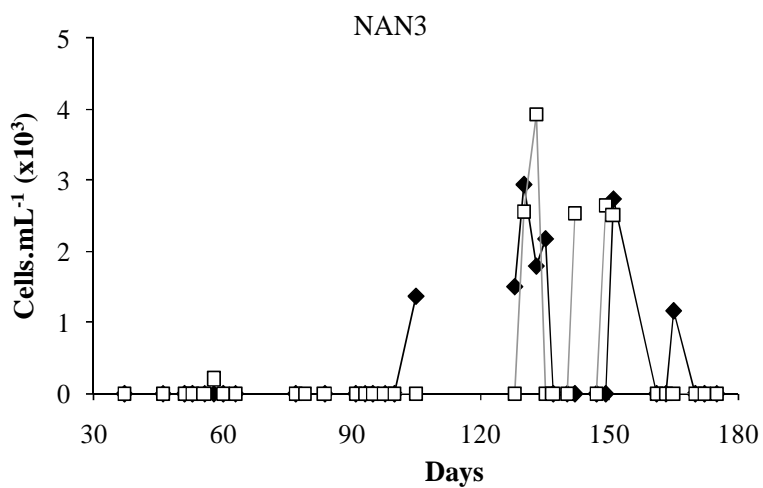

b

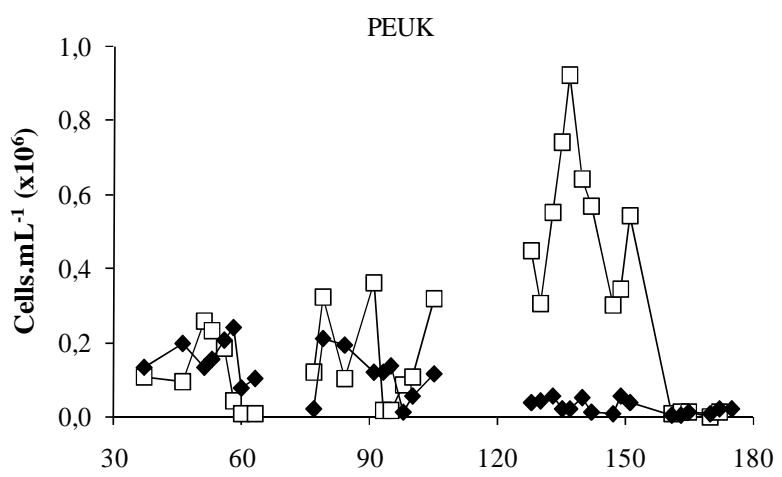

d

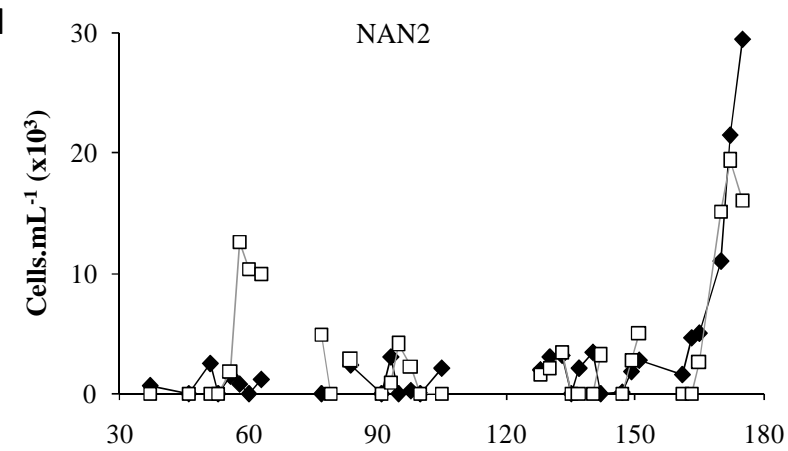

f

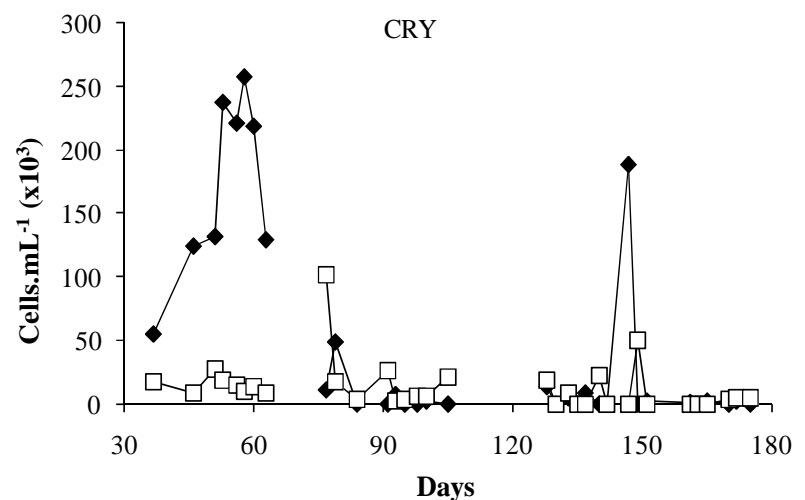

Fig. 3. Temporal variations of prokaryotic algae (UNK: unknown cyanobacteria; SYN: Synechococcus sp.), picoeukaryotes (PEUK), nanophytoplankton of increasing size (type 1,2 3) and Cryptophytes (CRY) densities in the water column of the two ponds. Abundances are expressed in million or thousand cells per ml. 


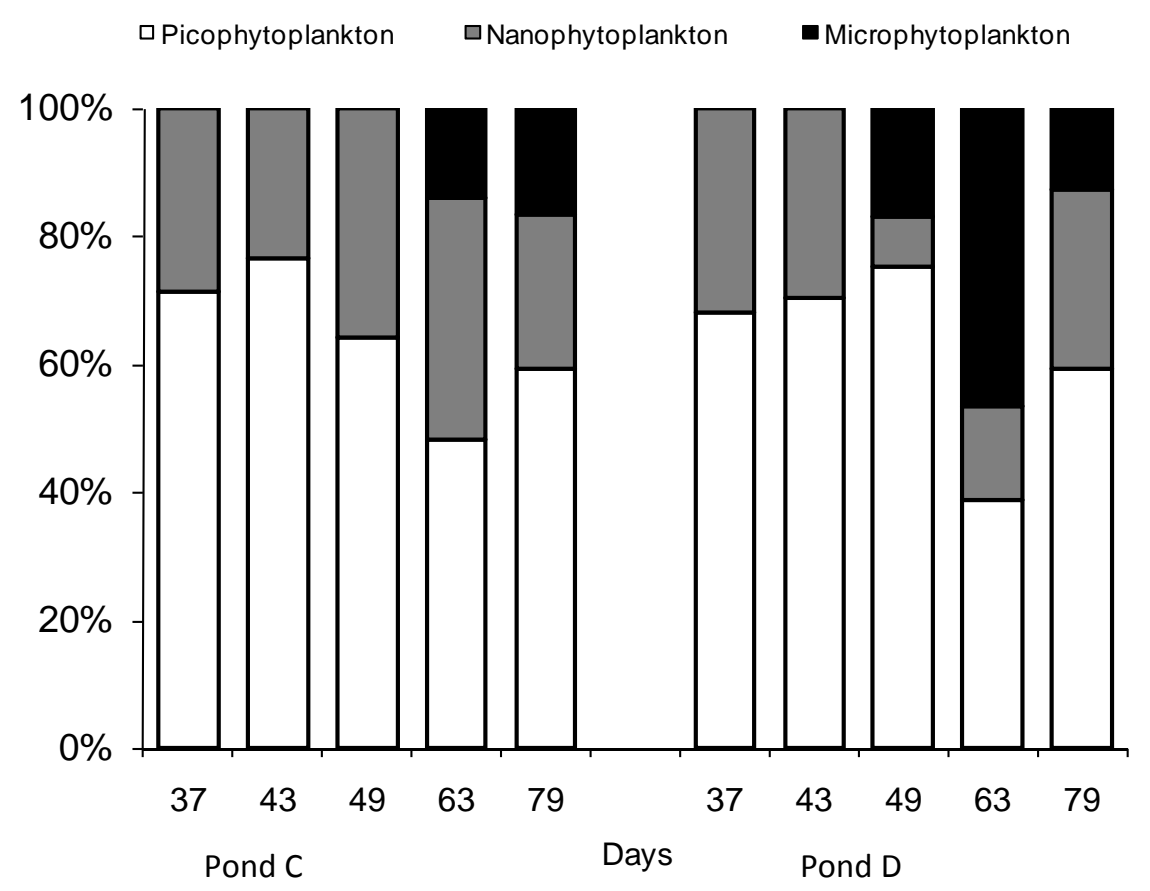

Fig. 4. Temporal variation of the size-fractionated Chlorophyll a biomass in the two ponds. 

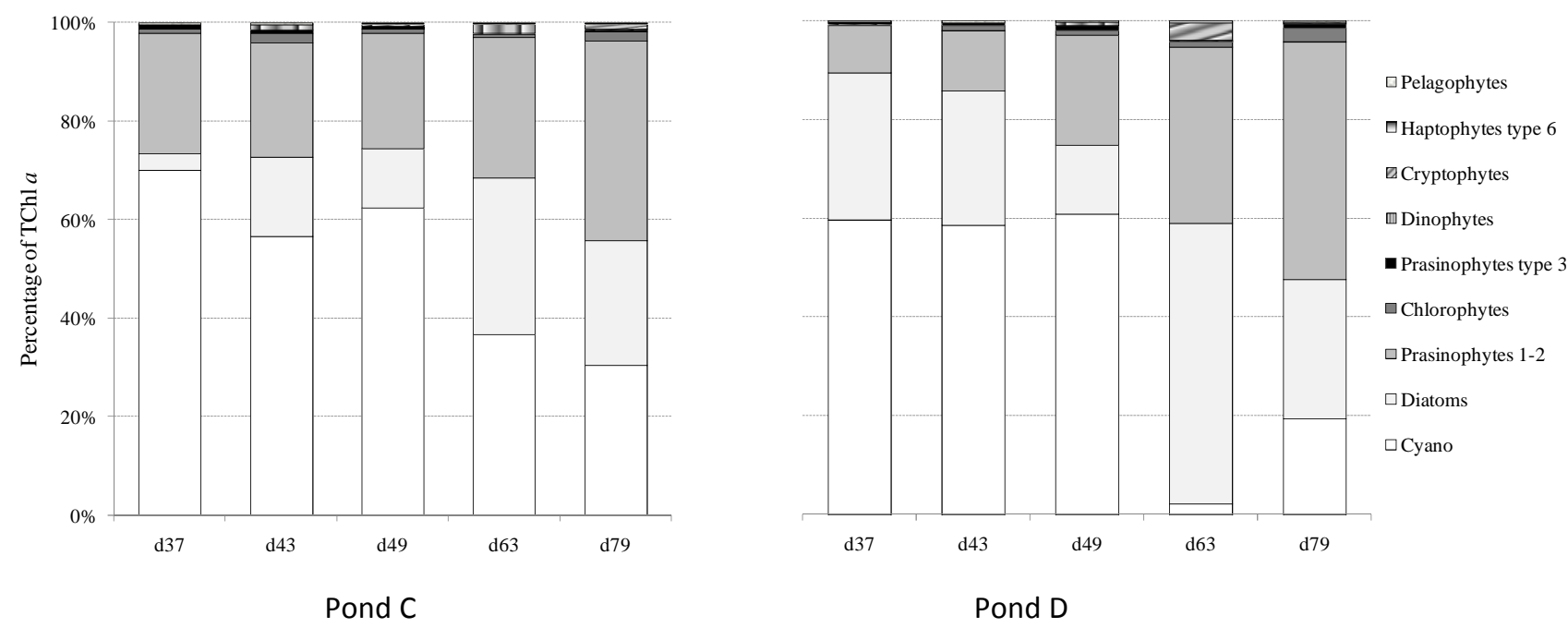

Fig. 5. Temporal variation of the distribution (\% of TChla) of the phytoplankton groups in the two ponds between $\mathrm{d} 37$ and d79. First mortalities were observed in both ponds between $\mathrm{d} 63$ and $\mathrm{d} 69$. 

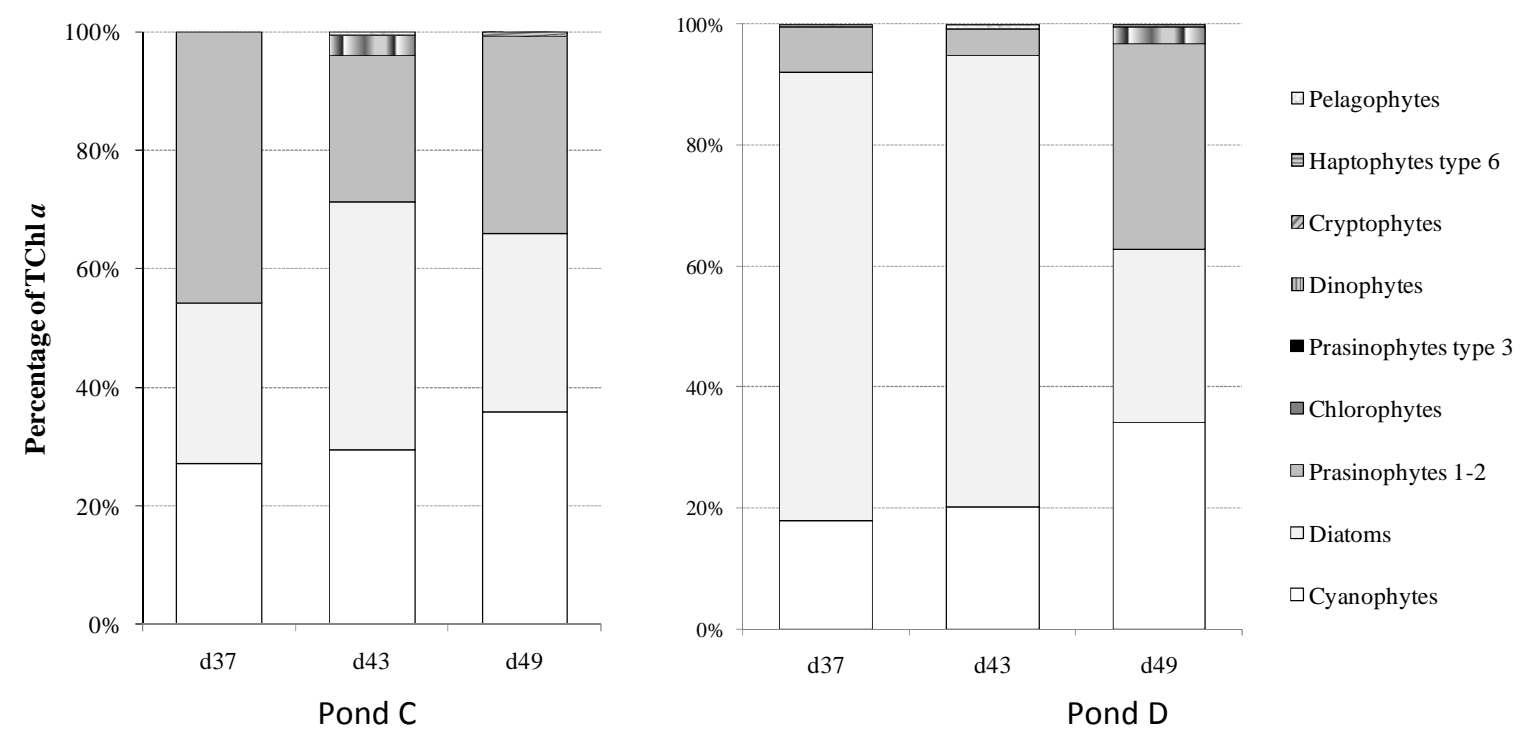

Fig. 6. Distribution (\% of TChla) of the phytoplankton groups belonging to the size fraction $2-20 \mu \mathrm{m}$ in the two ponds before the first mortality outbreak. 